\title{
State of The Art Strategies for Successful ANAMMOX Startup and Development: A Review
}

Suneethi $\mathbf{S}^{1 *}$, Sri Shalini $\mathbf{S}^{1}$ and Kurian Joseph ${ }^{2}$

Research Scholar, Centre for Environmental Studies, Anna University, India

\begin{abstract}
ANAMMOX (Anaerobic ammonium oxidation) bacteria, leading proponent of autotrophic ammonia removal, requires dedicated enrichment and cultivation techniques due to its slow growth rate and low biomass yield. Sensitivity to inhibitory concentrations of $\mathrm{NO}_{2}^{-}-\mathrm{N}, \mathrm{O}_{2}$ etc., often present in industrial effluents makes ANAMMOX startup difficult to achieve. In this paper, significant parameters for ANAMMOX startup and development such as source of seed, type of reactors used, one and two stage ANAMMOX process, operational strategies and experimental conditions promoting long term enrichment, cultivation and quantitative analysis with biomass retention are discoursed in detail. Key chemical and molecular signatures including $\mathrm{NO}_{2}^{-}-\mathrm{N}$, Alkalinity, $\mathrm{O}_{2}$, Polymerase chain reaction (PCR), Fluorescence in situ hybridization (FISH), Scanning electron microscopy (SEM), inhibitors and affinity factors for ANAMMOX activity are deliberated. Summary of state of the art on ANAMMOX enrichment, recommendations for future research with specific contributions of this paper to scientific community is brought out in conclusion.
\end{abstract}

Keywords: ANAMMOX; Enrichment; Startup; Growth rate; $\mathrm{NH}_{4}^{+}{ }^{+} \mathrm{N}$ removal

\section{Introduction}

Anaerobic ammonium oxidizers (ANAMMOX), the often overlooked key player in Nitrogen cycle, are involved in highly complex autotrophic microbial interactions to remove $\mathrm{NH}_{4}^{+}-\mathrm{N}$ from nitrogen rich wastewaters. In this process $\mathrm{NH}_{4}^{+}-\mathrm{N}$ is directly converted into dinitrogen gas using $\mathrm{NO}_{2}^{-}-\mathrm{N}$ as electron acceptor under anaerobic conditions. The ANAMMOX reaction was first observed in an anoxic denitrifying fluidized bed reactor (FBR) in Gist-Brocades, Delft, Netherlands, treating the effluent from a methanogenic reactor [1]. An ammonium loading rate of $0.4 \mathrm{gNH}_{4}^{+}-\mathrm{N} / \mathrm{L} / \mathrm{d}$ was removed in this system. The stoichiometry of the ANAMMOX reaction is represented by the following Equation (1).

$\mathrm{NH}_{4}+1.32 \mathrm{NO}_{2}^{-}+0.066 \mathrm{HCO}_{3}^{-}+0.13 \mathrm{H}^{+} \rightarrow 1.02 \mathrm{~N}_{2}+0.26 \mathrm{NO}_{3}^{-}+$ $0.066 \mathrm{CH}_{2} \mathrm{O}_{0.5} \mathrm{~N}_{0.15}+2.03 \mathrm{H}_{2} 0$

The ANAMMOX reaction is carried out by members of deeply branched Planctomycetes, such as 'Candidatus brocadia anammoxidans, Candidatus kuenenia stuttgartiensis, Candidatus scalindua, Candidatus anammoxoglobus and Candidatus jettenia' which makes use of $\mathrm{NH}_{4}^{+}-\mathrm{N}$ as the electron donor (energy source) and $\mathrm{NO}_{2}^{-}-\mathrm{N}$ as the electron acceptor. These autotrophs utilize dissolved $\mathrm{CO}_{2}$ or $\mathrm{HCO}_{3}^{-}$for cell biosynthesis [2-5].

Due to the notorious slow growth rate and low biomass yield $(0.13 \mathrm{~g}$ dry weight/g $\mathrm{NH}_{4}^{+}-\mathrm{N}$ oxidized) of ANAMMOX bacteria, dedicated enrichment and cultivation techniques are required [6-9]. The average doubling time of ANAMMOX bacteria is reported to be $14 \mathrm{~d}$ [10]. Doubling times as low as $5.3 \mathrm{~d}$ and $8.9 \mathrm{~d}$ were achieved by Park et al. (2010) [11], whilst 11d and 14d were reported by Strous et al. (1998) [12], Li et al. (2009) [9], Strous et al. (2006) [10] from ANAMMOX enriched laboratory scale reactors. The doubling time from the fullscale studies by Van der star et al. (2007) [13] were about 8.3 to $11 \mathrm{~d}$, while Third et al. (2005) [8] achieved 12d. The main bottlenecks of the ANAMMOX process could be ascribed to the low yield $(0.14 \mathrm{gVSS} / \mathrm{g}$ $\left.\mathrm{NH}_{4}^{+}-\mathrm{N}\right)$ and slow growth rate of ANAMMOX bacteria $\left(0.003 \mathrm{~h}^{-1}\right.$; $0.072 \mathrm{~d}^{-1}$ at $32^{\circ} \mathrm{C}$ ) and difficulty in isolating ANAMMOX bacteria in pure cultures $[7,12]$. Besides these rate limiting factors, presence of
$\mathrm{NO}_{2}^{-}-\mathrm{N}$, oxygen at critical concentrations can reversibly/irreversibly inhibit ANAMMOX process $[1,12,14]$.

The low growth rate combined with the sensitivity of the microorganisms to inhibitory concentrations of some compounds that are often present in industrial effluents makes the startup of the ANAMMOX process very difficult to achieve. The startup period can be minimized by selecting an appropriate seed biomass and running a suitable reactor configuration that promotes long term enrichment, cultivation and quantitative analysis with biomass retention. Proper control and monitoring of key parameters with no compromise on $\mathrm{NH}_{4}^{+}-\mathrm{N}$ removal rates is essential. Some of the important parameters that play a significant role during ANAMMOX enrichment are the source of seed, type of reactors used, operational strategy and experimental conditions. In this paper, the different ANAMMOX enrichment procedure from seeds of different origin is evaluated and the key parameters (both chemical and molecular) that enable both quick growth of ANAMMOX bacteria and affect its growth rate are identified.

\section{Key Parameters for ANAMMOX Enrichment}

\section{Source of seed}

ANAMMOX bacteria could be developed and applied to startup new reactors from obtaining enriched seed from already operational ANAMMOX reactors which is already containing significant composition of ANAMMOX populations. The long startup period could be reduced and a number of ANAMMOX operational reactors could be initiated simultaneously. Full-scale ANAMMOX reactors are

*Corresponding author: Suneethi S, Research Scholar, Centre for Environmental Studies, Anna University, Chennai- 600 025, India, Tel: 91-44-22301283; Fax: 09144-22354717 / 22201480; E-mail: sundar.suneethi@gmail.com

Received November 21, 2014; Accepted December 30, 2014; Published December 31, 2014

Citation: Suneethi S, Sri Shalini S, Joseph K (2014) State of The Art Strategies for Successful ANAMMOX Startup and Development: A Review. Int J Waste Resources 4: 168. doi: 10.4172/2252-5211.1000168

Copyright: (c) 2014 El Suneethi S, et al. This is an open-access article distributed under the terms of the Creative Commons Attribution License, which permits unrestricted use, distribution, and reproduction in any medium, provided the original author and source are credited. 
operational in Netherlands, Austria, and Germany and in other parts of Europe and USA. ANAMMOX process application can be developed by giving attention to application of enriched seed biomass for startup, since ANAMMOX process consumed long startup period ( $>200 \mathrm{~d}$ ) [15]. But as of date, it has not been possible to achieve a pure culture of any ANAMMOX bacteria. It could be attributed to the fact that the activities or presence of other organisms such as AOBs and NOBs are required for them to grow in mixed cultures. ANAMMOX process could also be initiated from non enriched seeds that are availed locally when enriched seed is unavailable and/or exotic enriched seeds could be deemed unsuitable for local conditions.

Inoculation of enriched ANAMMOX seed can accelerate the startup operation within 2 months, while inoculation from non enriched locally available seed may take longer than 4 months $[6,16]$. Date et al. (2009) [16] carried out ANAMMOX enrichment using sewage, digester and nitrifying sludge as seed in non-woven fabric carrier for immobilization. Besides the simultaneous removal of $\mathrm{NH}_{4}^{+}-\mathrm{N}$ and $\mathrm{NO}_{2}^{-}-\mathrm{N}$ and generation of $\mathrm{NO}_{3}^{-}-\mathrm{N}$ indicative of ANAMMOX activity, it was also reported that $\mathrm{NH}_{4}{ }^{+}-\mathrm{N}_{\text {removed }}: \mathrm{NO}_{2}{ }^{-}-\mathrm{N}_{\text {removed }}: \mathrm{NO}_{3}{ }^{-}-\mathrm{N}_{\text {produced }}$ was 1:1.02:0.23, 1:1.19:0.25 and 1:1.31:0.33 for sewage, digester and nitrifying sludge respectively. The evaluation of efficacy of ANAMMOX process from both enriched and non enriched seeds are depicted in Table 1.

\section{Experimental condition}

Gas sparging: Sparging the feed tank and ANAMMOX reactor with inert gases such as $\mathrm{Ar} / \mathrm{CO}_{2}$ or $\mathrm{N}_{2} / \mathrm{CO}_{2}$ with $95 / 5 \%$ composition enables to maintain strict anaerobic condition for ANAMMOX enrichment. Oxygen leakage that could occur from recirculation operations would require strict deoxygenation steps by sparging. In any case, the gas mixture should contain about $5 \% \mathrm{CO}_{2}$ in order to buffer the medium. Although there are reports of ANAMMOX enrichment under aerobic conditions [17-19], anaerobic conditions at least during the first periods of enrichment is advisable due to the high susceptibility of ANAMMOX bacteria to even microaerobic conditions [17].

Light : Light is considered to be inhibitive to ANAMMOX bacteria since it leads to the undesirable growth of phototrophic algal growth [20]. Studies were conducted by Uyanik et al. (2011) [20] which compared the operation of ANAMMOX reactors with and without control over light penetration. The ANAMMOX reactors that were operated with control over light penetration achieved ANAMMOX enrichment within $50 \mathrm{~d}$ of startup compared to $100 \mathrm{~d}$ taken by ANAMMOX reactors that was exposed to light. The reactors that were covered and kept in dark room favored no development of photosynthetic $\mathrm{O}_{2}$ production and algal development.

Addition of $\mathrm{NO}_{3}^{-}-\mathrm{N}, \mathrm{N}_{2} \mathrm{H}_{4}$ and $\mathrm{NH}_{2} \mathrm{OH}$ : During ANAMMOX startup from non enriched seeds, $\mathrm{NO}_{3}^{-}-\mathrm{N}$ concentration of about $(10-50 \mathrm{mg} / \mathrm{L})$ is usually added [20]. Under anaerobic condition, the organic load found in the seed biomass and those produced from initial decomposition could drive the process towards denitrification against the favor of ANAMMOX bacteria. This is due to the autotrophic nature of ANAMMOX bacteria. The addition of $\mathrm{NO}_{3}^{-}-\mathrm{N}$ into the reactors was used to feed heterotrophic denitrification bacteria in order for them to consume the organic compounds. It has been reported that addition of $\mathrm{NO}_{3}^{-} \mathrm{-}$ to the feed was effective on removal of organic load due to bacterial decomposition at the start of ANAMMOX enrichment [20]. In the startup phase, $\mathrm{NO}_{3}^{-}-\mathrm{N}$ is added to establish oxidative conditions, preventing the growth of other anaerobically respiring microorganisms such as sulfate reducers and methanogens. In response to the $\mathrm{NO}_{2}^{-}-\mathrm{N}$ consumption, its concentration in the feed is gradually increased [21] The idea of supplying $\mathrm{NO}_{3}^{-}-\mathrm{N}$ was that, since the inoculum contained an active denitrifying population, $\mathrm{NO}_{2}^{-} \mathrm{N}$ would be produced in the culture in low amounts by $\mathrm{NO}_{3}^{-}-\mathrm{N}$ reduction, using remaining organic compounds in the inoculum. The low amount of $\mathrm{NO}_{2}^{-}-\mathrm{N}$ production should be sufficient for any ANAMMOX bacteria present in the sludge. After the ANAMMOX reaction is clearly observed, $\mathrm{NO}_{3}$ $-\mathrm{N}$ addition should be discontinued because of both production of nitrate by ANAMMOX reaction and lack of interest in enrichment of denitrification bacteria.

From the works of Third et al. [8], addition of $0.1 \mathrm{mM}$ final reactor concentration $\mathrm{N}_{2} \mathrm{H}_{4} / \mathrm{NH}_{2} \mathrm{OH}$ to the ANAMMOX reactor was also reported to kick start the ANAMMOX process. The spiking of $\mathrm{N}_{2} \mathrm{H}_{4}$ and $\mathrm{NH}_{2} \mathrm{OH}$ was attempted to take advantage of the cyclic nature of the ANAMMOX mechanism, since cells needed to invest reducing power to start their catabolism by producing $\mathrm{NH}_{2} \mathrm{OH}$ from nitrite. This initial energy barrier can be overcome by the direct addition of $\mathrm{NH}_{2} \mathrm{OH}$ or $\mathrm{N}_{2} \mathrm{H}_{4}[8,12]$.

Shear stress: Thorough mixing condition inside the ANAMMOX reactor is important so as to avoid accumulation of $\mathrm{NO}_{2}^{-}-\mathrm{N}$ that could inhibit ANAMMOX activity. The speed of stirrer which is used to mix contents in ANAMMOX reactors influences the stability of ANAMMOX

\begin{tabular}{|c|c|c|c|c|c|}
\hline SI No & Origin of seed & $\begin{array}{l}\text { Highest Nitrogen Loading } \\
\text { rate }\left(\mathrm{kg} \mathrm{N} / \mathrm{m}^{3} / \mathrm{d}\right)\end{array}$ & $\begin{array}{c}\text { Highest Nitrogen Removal } \\
\text { Rate }\left(\mathrm{kg} \mathrm{N} / \mathrm{m}^{3} / \mathrm{d}\right)\end{array}$ & $\begin{array}{c}\text { Specific Nitrogen Removal } \\
\text { Rate (g N/g VSS/d) }\end{array}$ & Reference \\
\hline & \multirow{5}{*}{ Enriched ANAMMOX seed } & 0.28 & 0.08 & 0.13 & Padin et al. (2009) \\
\hline & & 1.2 & 0.75 & 0.18 & Van Dongen et al. (2001) \\
\hline & & 0.662 & 0.582 & - & Guven et al. (2004) \\
\hline & & 2.0 & 1.78 & 1.15 & Dapena-Mora et al. (2004a) \\
\hline & & 10.7 & 8.9 & - & Sliekers et al. (2003) \\
\hline & \multirow{3}{*}{ Activated sludge } & 2.6 & 2.4 & 0.30 & Fux et al. (2002) \\
\hline & & 1.6 & 1.57 & 0.92 & Lopez et al. (2008) \\
\hline & & 0.08 & 0.072 & 0.35 & Wang et al. (2009) \\
\hline & Anaerobic sludge digester & 0.231 & 0.216 & 0.43 & Bagchi et al. (2010) \\
\hline & Anaerobic/Aerobic granular sludge & 2.5 & 2.5 & - & Yang et al. (2006) \\
\hline & Anaerobic granular sludge & $125-137.1$ & $74.3-76.7$ & - & Tang et al. (2011) \\
\hline & Full-scale UASB & 0.015 & 0.009 & 0.64 & Tran et al. (2006) \\
\hline & \multirow{3}{*}{ Denitrifying reactor } & 58.5 & 26 & 1.6 & Tsushima et al. (2007) \\
\hline & & 1 & 1.8 & 180 & \multirow{2}{*}{ Strous et al. (1997) } \\
\hline & & 1.2 & 1.5 & 150 & \\
\hline
\end{tabular}

Table 1: Nitrogen removal efficiency achieved by ANAMMOX process from both enriched and non enriched seeds. 
granules [22]. The stirring speed in the range of $60-250 \mathrm{rpm}$ was tested by Arrojo et al. [22]. It was reported that upto 180rpm (input power between 0.003 and $\left.0.09 \mathrm{~kW} / \mathrm{m}^{3}\right)$ there was no significant effect on the performance of ANAMMOX process. ANAMMOX activity was reduced by $40 \%$ when the stirring speed was increased to $250 \mathrm{rpm}$ (input power $0.23 \mathrm{~kW} / \mathrm{m}^{3}$ ). The biomass retention worsened due to the breakage of the granules and floatation caused by nitrite accumulation. This caused a loss of the system efficiency due to a combination of cellular lysis and granules breakage. The increase of stirrer speed which involves an increase of shear stress was found to provoke the changes on the properties of biomass aggregates and on the system efficiency [22]. Due to rise in shear stress the rupture of the granules or even the detachment of weak patches of biomass from the surface of the granules could result in increase of suspended solids washout of the reactor. This is due to the biomass flotation that is closely related to the $\mathrm{NO}_{2}^{-}-\mathrm{N}$ accumulation in the system [15].

\section{Reactor Configurations}

High $\mathrm{NH}_{4}^{+}$-N removal rates could be obtained using ANAMMOX process in two ways: two reactors in series, with a partial nitrification reactor as a first step, and a separate unit for the anaerobic oxidation of $\mathrm{NH}_{4}^{+}-\mathrm{N}$ as a second step. With this configuration, the two biological processes can be controlled separately [23]. The second option was to use biofilm systems where classical nitrification is developed by the ammonium oxidizers in the outer aerobic layers, and anaerobic oxidation takes place in the deeper zones of the biofilm [23]. Application of ANAMMOX process or coupling partial nitrification with ANAMMOX seemed promising. It could result in $60 \%$ savings in $\mathrm{O}_{2}$ generation, $100 \%$ savings of external carbon source addition, less sludge production and $\mathrm{CO}_{2}$ emission, with a total reduction in treatment cost by $90 \%$ [14,24-26].

\section{One stage ANAMMOX process}

Direct application of ANAMMOX process was adopted by $\mathrm{Xu}$ et al. [27] to treat $\mathrm{NH}_{4}{ }^{+}-\mathrm{N}$ rich leachate using Sequencing batch biofilm reactors (SBBR). The system was started up in $58 \mathrm{~d}$ and stabilized in $33 \mathrm{~d}$, with DO of 1.2-1.4 mg/L, under alternate periods of aeration and anoxic condition. The leachate was used by spiking it with $\mathrm{NH}_{4} \mathrm{Cl}$ to about 450 $\mathrm{mg} / \mathrm{L}$ prior to feeding as influent to SBBR. The organic load was in the range of $1876 \pm 547 \mathrm{mg} / \mathrm{L}$ of COD and $1048 \pm 436 \mathrm{mg} / \mathrm{L}$ of $\mathrm{BOD}_{5}$. NLR was optimized to $300 \mathrm{mg} / \mathrm{L} / \mathrm{d}$, with $\mathrm{pH}$ around 7.3 to 7.8 without addition of alkali or acid. It was proposed that the repeated alteration between aeration and anoxic period made the acidity generated in the aeration phase neutralized in time by the alkalinity produced in the anoxic phase. The ratio of $\mathrm{NH}_{4}{ }^{+} \mathrm{N} / \mathrm{NO}_{2}{ }^{-} \mathrm{N}$ was in the range of 1.058 to 1.074 in the aeration phase, and 0.558 to 0.776 in the anoxic phase, as compared to the theoretical value of 0.758 in ANAMMOX reaction [12]. It was proven that anoxic condition favored ANAMMOX activity when weighed against oxic condition.

While Guo and Qi [28] treated aged landfill leachate in an Upflow anaerobic sludge blanket (UASB) ANAMMOX bioreactor (HRT 24h) and achieved about $80 \%$ total nitrogen removal efficiency from influent containing $900 \mathrm{mg}$ TN/L and $88 \% \mathrm{NH}_{4}^{+}-\mathrm{N}$ removal from an influent of $350 \mathrm{mg} \mathrm{NH}_{4}^{+}$-N/L. During the study period for $>200 \mathrm{~d}$, the mean COD removal was $24 \%$ from an influent of $1000 \mathrm{mg} / \mathrm{L}$. While alkalinity concentrations of both the influent and effluent during the steady phase of ANAMMOX activity were $1 \mathrm{~g} / \mathrm{L}$ and $\mathrm{pH}$ of influent and effluent were 8.3. This study indicated that alkalinity and $\mathrm{pH}$ could also be used to monitor the ANAMMOX activity. The ratio of $\mathrm{NO}_{2}^{-}-\mathrm{N} / \mathrm{NH}_{4}^{+}-\mathrm{N}$ was in the range of 0.96 to 1.49 , as compared to the stoichiometric value of $1.24[12]$.

Application of ANAMMOX process to remove $\mathrm{NH}_{4}^{+}-\mathrm{N}(1545 \mathrm{mg} / \mathrm{L})$ from wastewaters was performed by Sliekers et al. [29] in a gas lift reactor. The highest NLR reached during the ANAMMOX process was $10.3 \mathrm{kgN} / \mathrm{m}^{3} / \mathrm{d}$ with $\mathrm{Ar} / \mathrm{CO}_{2}$ sparged at flow of $200 \mathrm{~mL} / \mathrm{min}$. The ANAMMOX process was maintained in a gas lift reactor by maintaining anoxic condition during ANAMMOX process. NRR of $8.9 \mathrm{kgN} / \mathrm{m}^{3} / \mathrm{d}$ was achieved for the ANAMMOX process.

For one stage ANAMMOX reactors, besides the $\mathrm{NO}_{2}^{-}-\mathrm{N}$ limitation, $\mathrm{O}_{2}$ consumption by AOB plays a role in process design. $\mathrm{O}_{2}$ transfer was indeed indicated as the limiting process for a lab-scale air-lift [29] and for a lab scale moving bed reactor [8]. The $\mathrm{O}_{2}$ limitation could have originated from the slow diffusion into the biofilm or from the gas-liquid transfer. It was reported by Van der Star et al. [13] that $\mathrm{O}_{2}$ penetration is limiting the rotating disk contactor and the moving bed reactor with conversions of 2.5 and $1.2 \mathrm{~kg} \mathrm{~N} / \mathrm{m}^{3} / \mathrm{d}$, respectively. For the other reactors, gas-liquid oxygen transfer is potentially limiting as well. With a superficial gas velocity of $0.025 \mathrm{~m} / \mathrm{s}$ the oxygen transfer is approximately $15 \mathrm{~kg} \mathrm{O} / \mathrm{m}^{3} / \mathrm{d}$ (equivalent to a conversion of $8 \mathrm{~kg}-\mathrm{N} /$ $\mathrm{m}^{3} / \mathrm{d}[13,29]$.

\section{Two stage ANAMMOX process}

Application of coupling partial nitrification with ANAMMOX process was adopted by Liang and Liu [30] while treating landfill leachate $\left(\mathrm{NH}_{4}^{+}-\mathrm{N} 1500\right.$ to $\left.2500 \mathrm{mg} / \mathrm{L}\right)$. An integrated Partial nitritation - ANAMMOX reactor - Underground soil infiltration system was applied. ANAMMOX operation was performed by upflow fixed bed biofilm reactor and achieved $67 \% \mathrm{NH}_{4}^{+}-\mathrm{N}$ and $77 \% \mathrm{NO}_{2}^{-}-\mathrm{N}$ removal within $97 \mathrm{~d}$. The effluent of the partial nitritation process yielded a suitable influent for ANAMMOX process, by yielding 50\% partial conversion of $\mathrm{NH}_{4}^{+}-\mathrm{N}$ to $\mathrm{NO}_{2}^{-}-\mathrm{N}$ (ratio 1:1.3) favoring anaerobic ammonium oxidation. Nearly $60 \%$ of $\mathrm{NH}_{4}^{+}-\mathrm{N}$ removal was achieved by the end of ANAMMOX process, and $97 \%$ removal was obtained at the end of the combined treatment train. From the initial COD of $1100-2500 \mathrm{mg} / \mathrm{L}$, nearly $89 \%$ COD was removed with the final effluent showing $30-250 \mathrm{mg} / \mathrm{L}$, where nearly $32 \%$ COD was removed by ANAMMOX process. The main limitation of the process could be ascribed to the low yield and slow growth rate of ANAMMOX bacteria resulting in slow removal of $\mathrm{NO}_{3}^{-}-\mathrm{N}$ (half the time taken for aerobic nitrification) $[7,8,12]$.

The investigation of the aquatic humic substances (AHS) degradation by ANAMMOX process was conducted by Liang et al. [31] where the initial partial nitritation reactor was run for $166 \mathrm{~d}$ continuously using raw leachate, with $\mathrm{NH}_{4}^{+}-\mathrm{N}$ of 1430 to $2720 \mathrm{mg} / \mathrm{L}$ and COD of 1170 to $2600 \mathrm{mg} / \mathrm{L}$. Upon removal of VFA and acquiring the proper mixture of $\mathrm{NO}_{2}^{-}-\mathrm{N}$ to $\mathrm{NH}_{4}^{+}-\mathrm{N}$ ratio, this effluent with $\mathrm{NH}_{4}^{+}-\mathrm{N}$ of 506 to $885 \mathrm{mg} / \mathrm{L}$ and COD 303 to $954 \mathrm{mg} / \mathrm{L}$ was further treated in ANAMMOX reactor. The pretreatment in partial nitritation enabled removal of biodegradable organics from raw leachate, resulting in higher content of AHS in the feed to ANAMMOX reactor $(228 \mathrm{mg} / \mathrm{L})$. The effluent from ANAMMOX reactor is reduced to $91 \mathrm{mg} / \mathrm{L}$. The Dissolved organic carbon (DOC) was also reduced from 288 to $136 \mathrm{mg} / \mathrm{L}$ in the ANAMMOX reactor.

Furukawa et al. [32] successfully demonstrated partial nitritation using nitrifying activated sludge entrapped in a polyethylene glycol (PEG) gel carrier, as a pretreatment to ANAMMOX process for treating supernatant of anaerobically digested sludge. The partial nitritation 
reactor was operated at a NLR of $3.0 \mathrm{kgN} / \mathrm{m}^{3} / \mathrm{d}$ and suspended solids (SS) concentration of 2000 to $3000 \mathrm{mg} / \mathrm{L}$ that resulted in effluent with a $\mathrm{NO}_{2}-\mathrm{N} / \mathrm{NH}_{4}^{+}-\mathrm{N}$ ratio between 1.0 and 1.4 that was suitable for ANAMMOX process. The ANAMMOX reactor achieved TN removal rates of $4.0 \mathrm{kgN} / \mathrm{m}^{3} / \mathrm{d}$ under an applied nitrogen loading rate of 5.3 $\mathrm{kgN} / \mathrm{m}^{3} / \mathrm{d}$. The authors reported that entrapping ANAMMOX bacteria in the gel carrier prevented inhibition from influent COD and SS concentration. The mean $\mathrm{C} / \mathrm{N}$ ratio was $0.84 \mathrm{~g}$ TOC/g NH${ }_{4}^{+}-\mathrm{N}$ with no observed autotrophic ammonium oxidation inhibition.

Application of two stage partial nitritation and ANAMMOX process was also adopted by Fux et al. [33] for treating supernatant of anaerobically digested sludge. The partial nitritation was carried out in a continuous stirred tank reactor (CSTR) of working volume $2 \mathrm{~L}$ resulting in $58 \%$ conversion of $\mathrm{NH}_{4}^{+}-\mathrm{N}$ to $\mathrm{NO}_{2}^{-}-\mathrm{N}$. The ANAMMOX process was conducted in a Sequencing batch reactor (SBR) of working volume $1.6 \mathrm{~L}$ with nitrogen removal rate of $2.4 \mathrm{kgN} / \mathrm{m}^{3} / \mathrm{d}$, which constituted nearly $90 \%$ of the influent to ANAMMOX reactor. The nitrogen load to the ANAMMOX reactor was gradually increased based on the $\mathrm{NO}_{2}-\mathrm{N}$ concentration in the effluent, while the nitrogen removal was dependent on the ratio of $\mathrm{NO}_{2}^{-}-\mathrm{N} / \mathrm{NH}_{4}^{+}-\mathrm{N}$ in the influent.

Gali et al. [34] carried out studies to produce the influent for ANAMMOX process by partial nitrification process in SBR. The influent was the supernatant of anaerobically digested sludge of $\mathrm{NH}_{4}{ }^{+} \mathrm{N}$ concentration of 700 to $800 \mathrm{mg} \mathrm{N} / \mathrm{L}$ with low $\mathrm{HCO}_{3}^{-} / \mathrm{NH}_{4}^{+}-\mathrm{N}$ ratio favoring partial nitrification. Complete nitrification required $2 \mathrm{~mol}$ of $\mathrm{HCO}_{3}^{-}$for each mol of $\mathrm{NH}_{4}^{+}-\mathrm{N}$, whereas the $\mathrm{HCO}_{3}^{-} / \mathrm{NH}_{4}^{+}-\mathrm{N}$ ratio was 1 for the influent, which bodes well for partial nitrification. The SBR was operated in 4 stages such as aerobic filling ( $5 \mathrm{~min})$, mixing (210min), settling (20min) and drawing ( $5 \mathrm{~min})$. By the end of 5 months the partial nitrification process yielded $50 \% \mathrm{NH}_{4}^{+}-\mathrm{N}$ removal efficiency with specific ammonium uptake rate of $42 \mathrm{mg} \mathrm{NH}_{4}{ }^{+}-\mathrm{N} / \mathrm{g}$ VSS $/ \mathrm{h}$.

Partial nitritation-ANAMMOX process was applied for treating livestock manure by Yamamoto et al. [35]. The partial nitritation reactor was maintained for $32 \mathrm{~d}$ under NLR of $1.6 \mathrm{kgN} / \mathrm{m}^{3} / \mathrm{d}$ resulted in mean conversion efficiency of $51 \%$. The partial nitritation reactor achieved $1.65 \mathrm{kgN} / \mathrm{m}^{3} / \mathrm{d}$ of maximum $\mathrm{NO}_{2}-\mathrm{N}$ production rate under NLR of $2.58 \mathrm{kgN} / \mathrm{m}^{3} / \mathrm{d}$. The ANAMMOX process was performed in a UASB reactor that achieved nearly $2.0 \mathrm{kgN} / \mathrm{m}^{3} / \mathrm{d}$ under a NLR of $2.2 \mathrm{kgN} /$ $\mathrm{m}^{3} / \mathrm{d}$. Another partial nitritation-ANAMMOX study was conducted by Yamamoto et al. [35] for treating livestock manure effluent of $\mathrm{NH}_{4}^{+}-\mathrm{N}$ concentration in the range of 2000 to $4000 \mathrm{mg} / \mathrm{L}$. The partial nitritation reactor was maintained at NLR of $1.0 \mathrm{kgN} / \mathrm{m}^{3} / \mathrm{d}$ for over 4 months which was followed by the ANAMMOX reactor. The conversion efficiency of $\mathrm{NH}_{4}^{+}-\mathrm{N}$ to $\mathrm{NO}_{2}^{-}-\mathrm{N}$ and $\mathrm{NH}_{4}^{+}-\mathrm{N}$ to $\mathrm{NO}_{3}^{-}-\mathrm{N}$ were estimated to be $58 \%$ and $<5 \%$ respectively. The ANAMMOX process yielded consistent nitrogen removal rate of $0.22 \mathrm{kgN} / \mathrm{m}^{3} / \mathrm{d}$.

Leachate pretreatment prior to ANAMMOX reactor using SBR was studied by Ganigue et al. [36]. By adopting a step feed strategy, with alteration between aerobic and anoxic condition, leachate of $5000 \mathrm{mg}$ $\mathrm{NH}_{4}^{+}$-N/L was partially nitrified and obtained in the required ratio of 1:1.32. The effluent of 1500 to $2000 \mathrm{mg} \mathrm{NH}_{4}^{+}-\mathrm{N} / \mathrm{L}$ and 2000 to 3000 $\mathrm{mg} \mathrm{NO}-\mathrm{N} / \mathrm{L}$ was obtained. The reactor was operated for $450 \mathrm{~d}$ with NLR around $0.85 \mathrm{kgN} / \mathrm{m}^{3} / \mathrm{d}$ to $1.2 \mathrm{kgN} / \mathrm{m}^{3} / \mathrm{d}$. The suitable mixture of $\mathrm{NH}_{4}^{+}-\mathrm{N}$ and $\mathrm{NO}_{2}{ }^{-}-\mathrm{N}$ obtained was used as feed for ANAMMOX reactor. The presence of low concentrations of biodegradable organic matter (4357 $\pm 692 \mathrm{mg} \mathrm{COD} / \mathrm{L}$ ) in the leachate was used for denitrification. Supplementation of $\mathrm{HCO}_{3}^{-}$externally to favor partial nitritation was adopted, thereby increasing $\mathrm{NH}_{4}^{+}-\mathrm{N}$ conversion and $\mathrm{NO}_{2}^{-}-\mathrm{N}$ formation.

\section{Type of Reactor Operation}

It is important to comprehend the physical, chemical and the biological needs in the form of symbiotic relationships with key partners (AOBs, NOBs and ANAMMOX) in the mixed microbial community [37]. Hence the widespread strategy to obtain dense enrichments is by using batch cultures and different reactor types, both conventional and advanced configurations to facilitate the growth and development of ANAMMOX bacteria.

The slow growing ANAMMOX organism cannot be cultivated using conventional microbiological techniques [6]. Biological reactors are proven best for cultivating ANAMMOX bacteria $[4,6,12,15,26,38$ 41]. Batch cultures were applied for enrichment purposes to confirm a wide array of samples from different seed origins, to reduce the startup duration needed to reduce trial and error in biological reactors and to decrease the number of reactors for simultaneous enrichment [37]. To apply the ANAMMOX process, the choice of reactor type is very important. It should be suited for long term enrichment, cultivation and quantitative analysis [12]. Full-scale application of ANAMMOX process can be achieved by choosing the appropriate seed sludge and an adequate reactor configuration for ANAMMOX enrichment [42].

\section{ANAMMOX cultivation and enrichment in batch cultures}

Applying enrichment in batch studies will enable obtaining successful inocula for starting up ANAMMOX biological reactors. The physiological $\mathrm{pH}$ and temperature ranges to be maintained are 6.7 to 8.3 and $20^{\circ} \mathrm{C}$ to $43^{\circ} \mathrm{C}$ [14]. Well mixing is vital to maintain redox potential in the denitrification zone and sulfide formation has to be avoided. Sludge retention is important owing to the slow growth rates of the bacteria [6-8]. Replenishment of both Nitrogen supplements $\left(\mathrm{NH}_{4}^{+}-\mathrm{N}\right.$ and $\left.\mathrm{NO}_{2}^{-}-\mathrm{N}\right)$ and nutrients (enrichment medium) need to be performed to avoid substrate limitation.

In the batch study of ANAMMOX enrichment carried out by Sanchez - Melsio et al. [37], seed biomass were taken from natural environments and treatment plants, which included sediment samples from marine, brackish and freshwater system, seeds from WWTP digesters and from anoxic SBR systems. Enrichments were carried out in Erlenmeyer flasks, with $100 \mathrm{~mL}$ sample and $300 \mathrm{~mL}$ enrichment medium [43]. The enrichment flasks contained essential nutrients along with the presence of trace metals. $\mathrm{NH}_{4}{ }^{+}-\mathrm{N}$ and $\mathrm{NO}_{2}{ }^{-} \mathrm{N}$ were added as supplements step wise in order to increase the concentrations from $20 \mathrm{mg} / \mathrm{L}$. The enrichments were maintained in shaking incubator in the dark at $37^{\circ} \mathrm{C}$, with $\mathrm{pH}$ in the range of 6.7 to 8.3 . The presence and activity of ANAMMOX was confirmed through the changes in nitrogen compound consumption and by application of molecular analyses. Kawagoshi et al. [44] performed ANAMMOX enrichment from marine sediments. Candidatus Scalindua wagneri was observed in the enrichment reactor that was operated at NLR of $0.4 \mathrm{kgN} / \mathrm{m}^{3} / \mathrm{d}$. Mulder et al. [1] conducted batch studies with seed originating from FBR, with the $\mathrm{NH}_{4}^{+}-\mathrm{N}$ conversion capacity of $2.7 \mathrm{mg} \mathrm{NH}_{4}^{+}-\mathrm{N} / \mathrm{g}$ VSS/d. ANAMMOX activity was proved based on nitrogen and redox balances. It was concluded that $\mathrm{NH}_{4}^{+}-\mathrm{N}$ conversion was $\mathrm{NO}_{3}^{-}-\mathrm{N}$ dependent [1].

While Bagchi et al. [45] carried out ANAMMOX enrichment from a non enriched locally procured seed in a completely stirred tank reactor (CSTR) with HRT of $2 \mathrm{~d}$. Anaerobic digester sludge from a local STP with TSS and VSS of $38500 \mathrm{mg} / \mathrm{L}$ and $29800 \mathrm{mg} / \mathrm{L}$ was used as seed. The biomass was initially acclimatized in batch cultures incubated with synthetic medium and amoxicillin $(250 \mathrm{mg} / \mathrm{L})$. After $65 \mathrm{~d}$ of incubation, the sludge with VSS of $78000 \mathrm{mg} / \mathrm{L}$ was used as seed for 
CSTR. The synthetic wastewater of total nitrogen concentration $\left(\mathrm{NH}_{4}^{+}\right.$ $\mathrm{N}+\mathrm{NO}_{2}-\mathrm{N}$ ) of $115 \pm 5 \mathrm{mg} / \mathrm{L}$ was fed into CSTR. The NLR was increased as the ANAMMOX activity developed from $0.057 \pm 0.003 \mathrm{kgN} / \mathrm{m}^{3} / \mathrm{d}$ to $0.225 \pm 0.014 \mathrm{kgN} / \mathrm{m}^{3} / \mathrm{d}$. The presence of $\mathrm{AOB}$ was identified on the surface and on the exterior layers of granules and the NOB and ANAMMOX bacteria inside. The $\mathrm{NO}_{2}^{-}-\mathrm{N}^{-} \mathrm{NH}_{4}{ }^{+} \mathrm{N}$ was adjusted to enable ANAMMOX activity sustenance even in the presence of mixed community. The highest NRR obtained was $0.216 \mathrm{kgN} / \mathrm{m}^{3} / \mathrm{d}$ and highest specific NRR was $0.434 \mathrm{~g} \mathrm{~N} / \mathrm{g} \mathrm{VSS} / \mathrm{d}$. It was also reported that the ANAMMOX activity in this system was not inhibited by $\mathrm{NH}_{3}$ toxicity and the $\mathrm{pH}$ variations.

Batch tests were conducted by Chen et al. (2010) [46] in $500 \mathrm{~mL}$ flasks, for ANAMMOX enrichment, with temperature $\left(35^{\circ} \mathrm{C}\right), \mathrm{pH}(7-8)$ control and continuous mixing $(150 \mathrm{rpm})$. The anoxic condition was maintained by flushing with a gas mixture of $95 \% \mathrm{Ar}$ and $5 \% \mathrm{CO}_{2}$. The ANAMMOX enrichment was monitored by analyzing the initial and final substrate concentration for mass balance calculation. The initial $\mathrm{NH}_{4}^{+}-\mathrm{N}$ and $\mathrm{NO}_{2}^{-}-\mathrm{N}$ concentrations were $60 \mathrm{mg} / \mathrm{L}$ (each) and final substrate concentrations were $17 \mathrm{mg} / \mathrm{L}$ for $\mathrm{NH}_{4}^{+}-\mathrm{N}$ and $0 \mathrm{mg} / \mathrm{L}$ of $\mathrm{NO}_{2}-\mathrm{N}$ with effluent $\mathrm{NO}_{3}-\mathrm{N}$ of $9.7 \mathrm{mg} / \mathrm{L}$. The maximum Specific ANAMMOX activity (SAA) was determined to be $1.8 \mathrm{gN} / \mathrm{g} \mathrm{VSS} / \mathrm{d}$. Enrichment of ANAMMOX using immobilized microbial consortia was carried out by Pathak et al. (2007) [47]. It was performed at low nitrogen level $(<3 \mathrm{mg} / \mathrm{L})$ at low temperature $\left(20^{\circ} \mathrm{C}\right)$ in a laboratory scale upflow anoxic reactors. Nitrogen removal efficacy $>92 \%$ with the total nitrogen in the effluent $<0.2 \mathrm{mg} / \mathrm{L}$ was achieved upon operating for 300d.

ANAMMOX process is not inhibited by $\mathrm{NH}_{4}^{+}-\mathrm{N}$ or the byproduct $\mathrm{NO}_{3}^{-}-\mathrm{N}$ up to $1 \mathrm{~g}$ of $\mathrm{N} / \mathrm{L}$ [14]. The ANAMMOX process is completely inhibited by $\mathrm{NO}_{2}^{-}-\mathrm{N}>0.1 \mathrm{~g}$ of $\mathrm{N} / \mathrm{L}$. The $\mathrm{NO}_{2}^{-}-\mathrm{N}$ inhibition could be overcome by addition of trace amounts of either of the ANAMMOX intermediates $1.4 \mathrm{mg}$ of $\mathrm{N} / \mathrm{L}$ of $\mathrm{N}_{2} \mathrm{H}_{4}$ or $0.7 \mathrm{mg}$ of $\mathrm{N} / \mathrm{L}$ of $\mathrm{NH}_{2} \mathrm{OH}$, and enable restoration of the ANAMMOX activity [14]. $\mathrm{NO}_{2}^{-}-\mathrm{N}$ toxicity due to increase in substrate concentrations is addressed by recirculation of the effluent, thereby protecting the ANAMMOX sludge [46,48]. High $\mathrm{NO}_{2}^{-}-\mathrm{N}$ concentrations above $70 \mathrm{mg} / \mathrm{L}$ for 'Candidatus Brocadia Anammoxidans' and above 180mg/L 'Candidatus Kuenenia stuttgartiensis' for prolonged periods is harmful to the process, so is $\mathrm{O}_{2}$ concentration higher than $0.06 \mathrm{mg} / \mathrm{L}$ [24]. Complete irreversible inhibition of this process when $\mathrm{CH}_{3} \mathrm{OH}$ concentration is $\geq 40 \mathrm{mg} / \mathrm{L}$ $[23,49]$. Since there was an existing competition for dominance between ANAMMOX bacteria, denitrifiers and AOBs, it might be a problem while treating wastewaters with high organic (Carbon) and nitrogen content [40].

\section{ANAMMOX cultivation and enrichment in continuous systems}

The development and growth of ANAMMOX bacteria in a number of conventional biological reactors such as FBR, SBR, UASB etc., has been undertaken to evaluate the apt configuration for ANAMMOX enrichment and application in treating $\mathrm{NH}_{4}^{+}-\mathrm{N}$ rich wastewaters.

Fluidized Bed Reactor (FBR): The ANAMMOX activity was first reported in the denitrifying FBR treating effluent from a methanogenic reactor by Mulder et al. [1]. The FBR of $23 \mathrm{~L}$ volume was operated at $36^{\circ} \mathrm{C}$ and $\mathrm{pH} 7$ with HRT 4.2h. The anoxic liquid was recirculated to keep the bed fluidized of $255 \mathrm{~L} / \mathrm{h}$ flow with superficial liquid velocity 30 to $34 \mathrm{~m} / \mathrm{h}$. Sand particles were used as biocarrier with biofilm concentration of 150 to $300 \mathrm{mg}$ VSS/g carrier (14g VSS/L). During the initial $420 \mathrm{~d} \mathrm{NH}_{4}^{+}-\mathrm{N}$ concentrations was similar to effluent concentrations $(125 \mathrm{mg} / \mathrm{L})$.
From 420-560d the $\mathrm{NH}_{4}^{+}-\mathrm{N}$ concentration started to decrease (from $50 \mathrm{mg} / \mathrm{L}$ to $<5 \mathrm{mg} / \mathrm{L})$. Highest $\mathrm{NH}_{4}^{+}-\mathrm{N}$ removal rate of $0.4 \mathrm{kgN} / \mathrm{m}^{3} / \mathrm{d}$ was reported. Gas composition analysis (v/v) performed during the ANAMMOX process showed 68 to $72 \%$ of $\mathrm{N}_{2}, 15$ to $18 \%$ of $\mathrm{CH}_{4}, 13$ to $18 \%$ of $\mathrm{CO}_{2}$, while $\mathrm{N}_{2} \mathrm{O}$ was below the detection limit of $65 \mathrm{ppm}$.

Sequencing Batch Reactor (SBR): SBR was considered for ANAMMOX enrichment as it held the following strong points such as simplicity, efficient biomass retention, homogenous distribution of substrates, products and biomass aggregates in the reactor, reliable operation for long period ( $>1$ year), stable conditions under substrate limiting environment $[4,12]$. Using SBR, ANAMMOX process was successfully started in 4 months by Chamchoi and Nitisoravut [6] from sludge obtained from UASB, activated sludge and anaerobic digester. The initial biomass concentration in MLSS was $1500 \mathrm{mg} / \mathrm{L}$. The synthetic medium composition used was according to Van de Graaf et al. [43], with regular addition of $\mathrm{NH}_{4}^{+}-\mathrm{N}^{-}$and $\mathrm{NO}_{2}^{-}-\mathrm{N}(1: 1.5)$ at neutral $\mathrm{pH}$ (7.7 to 8.4). The ratio of $\mathrm{NH}_{4}^{+}-\mathrm{N}^{-}$to $\mathrm{NO}_{2}^{-}-\mathrm{N}$ in the feed was higher than the stoichiometric ratio of $1: 1.32$ [12]. The reactors were operated under anaerobic conditions, with reaction ( 5 to $7 \mathrm{~h})$, settling $(0.5 \mathrm{~h})$ and discharge periods $(0.25 \mathrm{~h})$. The reactor was kept at anaerobic condition with $\mathrm{Ar} / \mathrm{CO}_{2}$ (95/5\%) gas flushing. During the first 5 to 7 weeks after seeding, the effluent $\mathrm{NH}_{4}{ }^{+}-\mathrm{N}$ concentrations $(75 \mathrm{mg} / \mathrm{L})$ were higher than influent $(30 \mathrm{mg} / \mathrm{L})$. Significant removal of $\mathrm{NH}_{4}^{+}-\mathrm{N}$ and $\mathrm{NO}_{2}^{-}-\mathrm{N}(80$ and $100 \%$ ) along with small amounts of $\mathrm{NO}_{3}^{-} \mathrm{N}$ produced was observed in the initial three months of operation, indicative of ANAMMOX process [4]. Complete $\mathrm{NO}_{2}^{-}-\mathrm{N}$ removal was obtained in four months. The ratios obtained were $1: 1.5,1: 1.53$ and $1: 1.5$ for the three reactors containing seeds from UASB, activated sludge and anaerobic digester.

According to Liao et al. [42], granulation of ANAMMOX biomass is favored upon using SBR. Anaerobic methanogenic granular sludge was used (MLSS $72800 \mathrm{mg} / \mathrm{L}$ and MLVSS $63400 \mathrm{mg} / \mathrm{L}$ ) to startup SBR (7L volume). About $1 \mathrm{~L}$ of anaerobic granular sludge and $5 \mathrm{~L}$ of enrichment medium [43] were added to SBR with $\mathrm{N}_{2}$ gas sparging for fluidization of biomass with liquid and to maintain anaerobiosis of the reactor. The ANAMMOX activity showed improvement when the VSS concentrations reduced from 8.913 to $4.554 \mathrm{mg} / \mathrm{L}$ and VSS/SS ratio also reduced from 94 to $84 \%$.

Direct application of ANAMMOX process was adopted by $\mathrm{Xu}$ et al. [27] to treat $\mathrm{NH}_{4}^{+}-\mathrm{N}$ rich leachate using Sequencing batch biofilm reactors (SBBR). The system was started up in $58 \mathrm{~d}$ and stabilized in $33 \mathrm{~d}$, with DO level of $1.2-1.4 \mathrm{mg} / \mathrm{L}$, with alternate periods of aeration and anoxic condition. The leachate was used by spiking it with $\mathrm{NH}_{4} \mathrm{Cl}$ and regulated to about $450 \mathrm{mg} / \mathrm{L}$ with distilled water prior to feeding as influent to SBBR. The organic load was in the range of $1876 \pm 547 \mathrm{mg} / \mathrm{L}$ of COD and $1048 \pm 436 \mathrm{mg} / \mathrm{L}$ of $\mathrm{BOD}_{5}$. Nitrogen loading rate (NLR) was optimized to $300 \mathrm{mg} / \mathrm{L} / \mathrm{d}$, with $\mathrm{pH}$ around 7.3 to 7.8 without addition of alkali or acid. It was proposed that the repeated alteration between aeration and anoxic period made the acidity generated in the aeration phase neutralized in time by the alkalinity produced in the anoxic phase. The ratio of $\mathrm{NH}_{4}{ }^{+}-\mathrm{N} / \mathrm{NO}_{2}-\mathrm{N}$ was in the range of 1.058-1.074 in the aeration phase, and $0.558-0.776$ in the anoxic phase, as compared to the theoretical value of 0.758 in ANAMMOX reaction [12]. It was proven that anoxic condition favored ANAMMOX activity when weighed against oxic condition.

Rotating biological contactor (RBC): Liu et al. [39] developed ANAMMOX in rotating biological contactor (RBC) within $100 \mathrm{~d}$ by increasing the NLR in the influent feed with gradually shortened HRT. Influent concentration of $\mathrm{NH}_{4}^{+}-\mathrm{N}^{+}$and $\mathrm{NO}_{2}^{-}-\mathrm{N}$ was raised from 100 to $350 \mathrm{mg} / \mathrm{L}$, with initial HRT of $1 \mathrm{~d}$ and $99 \%$ and $97 \%$ of $\mathrm{NH}_{4}^{+}-\mathrm{N}^{-}$and $\mathrm{NO}_{2}$ 
$-\mathrm{N}$ removal efficiency was observed. Upon varying the HRT during optimization, after $100 \mathrm{~d}$ of operation, mean $\mathrm{NH}_{4}^{+}-\mathrm{N}$ removal of $99 \%$, $\mathrm{NO}_{2}-\mathrm{N}$ removal $100 \%$, TN removal $84 \%$ was achieved at $350 \mathrm{mg} / \mathrm{L}$ of $\mathrm{NH}_{4}^{+}-\mathrm{N}$ and $\mathrm{NO}_{2}^{-}-\mathrm{N}$ with HRT 4 h. Nearly $70 \%$ of nitrogen was removed in a nitrifying $\mathrm{RBC}$ for $\mathrm{NH}_{4}^{+}-\mathrm{N}$ rich leachate $(100$ to $400 \mathrm{mg} / \mathrm{L})$ from a hazardous waste landfill [26]. With a pretreated inflow of leachate from $\mathrm{RBC}$ at $30-170 \mathrm{~m}^{3} / \mathrm{d}$, the system was designed to nitrify $30 \mathrm{~kg} \mathrm{NH}_{4}^{+}-\mathrm{N} / \mathrm{d}$ $\left(3.7 \mathrm{gN} / \mathrm{m}^{2} / \mathrm{d}\right)$. The nitrogen elimination without organic carbon was attributed to ANAMMOX process, where the $\mathrm{NO}_{2}^{-}-\mathrm{N}$ produced in the aerobic biofilm layer by Nitrosomonas near the surface, is diffused and reduced by anaerobic ammonium oxidation in the lower anoxic layer by the ANAMMOX bacteria. Thus spontaneously both aerobic and anaerobic ammonia oxidation was developed on the biofilm [50].

Similarly in another study on $\mathrm{RBC}[51] \mathrm{NH}_{4}^{+}-\mathrm{N}$ conversion efficiency of 79\%, TN removal efficacy of $70 \%$ and COD removal of $94 \%$ was obtained at $0.69 \mathrm{kgN} / \mathrm{m}^{3} / \mathrm{d}$ and $0.34 \mathrm{~kg} / \mathrm{m}^{3} / \mathrm{d}$ of nitrogen and COD loading rates, respectively. The ANAMMOX reactors used were capably mixed with mechanical stirrer and uncommonly with recirculation of the produced $\mathrm{N}_{2}$ gas as well. Anoxic conditions were maintained by $\mathrm{N}_{2} / \mathrm{Ar} / \mathrm{CO}_{2}$ sparging $[4,6,15]$. In these biofilm studies, long term establishment of AOB and ANAMMOX communities occurred with limited scope for NOBs [50].

Gas Lift reactor: Dapena-Mora et al. [15] used both SBR and Gas lift reactor under anaerobic conditions with steady increment in $\mathrm{NH}_{4}^{+}-\mathrm{N}$ and $\mathrm{NO}_{2}^{-}-\mathrm{N}$ under maximum nitrogen load that could be treated by ANAMMOX. The SBR was operated in $330 \mathrm{~min}, 20 \mathrm{~min}$, $10 \mathrm{~min}$ of reaction, settling and discharge phases. The mean ratio of $\mathrm{NH}_{4}{ }^{+}-\mathrm{N}$ utilization to generation of $\mathrm{NO}_{2}{ }^{-} \mathrm{N}$ was 1:0.26 and 1:0.2 in the gas lift and SBR as compared to 1:0.04 by Chamchoi and Nitisoravut [6]. Sliekers et al. [29] also used Gas lift reactor for ANAMMOX and CANON processes. The $\mathrm{NH}_{4}{ }^{+}-\mathrm{N}$ removal by ANAMMOX and CANON process attained were 8.9 and $1.5 \mathrm{kgN} / \mathrm{m}^{3} / \mathrm{d}$ respectively. The reactor was initiated from an enriched seed from already operational ANAMMOX SBR. The gas lift reactor was operated as ANAMMOX mode and then followed by CANON mode. In the ANAMMOX mode, the NLR was $10.7 \mathrm{kgN} / \mathrm{m}^{3} / \mathrm{d}$ at $6.7 \mathrm{~h}$ HRT that achieved nearly $80 \%$ $\mathrm{NH}_{4}^{+}-\mathrm{N}$ removal. During the CANON mode of operation operated at 10h HRT, feed and effluent $\mathrm{NH}_{4}^{+}-\mathrm{N}$ concentrations were 1545 and 899 $\mathrm{mg} / \mathrm{L}$, respectively.

Upflow Anaerobic Sludge Blanket Reactor (UASB): Besides SBR, Gas lift reactor and RBC, ANAMMOX bacteria was also developed using UASB reactor too [38]. Granular sludge from anaerobic digester (18.6g VSS/L) was used as potential seed source. Recycling of sludge at $3 \mathrm{Q}$ ratios was applied to accelerate mixing and induce dilution of influent thereby reducing the $\mathrm{NO}_{2}^{-}-\mathrm{N}$ toxicity to ANAMMOX bacteria. Onset of $\mathrm{NH}_{4}^{+}-\mathrm{N}$ reduction was detected after 200d of sludge cultivation. The effluent $\mathrm{NH}_{4}^{+}-\mathrm{N}$ concentration exhibited steadfast reduction with $\mathrm{NO}_{2}^{-}-\mathrm{N}$ consumption and low production of $\mathrm{NO}_{3}^{-}-\mathrm{N}$ as byproduct. The color of the sludge turned from black to reddish brown, which is a well-documented characteristic of ANAMMOX activity $[6,7,38,41]$. After 11 months of operation, the stoichiometric ratio of the ANAMMOX reaction was maintained at 1:1.32 $\left(\mathrm{NH}_{4}^{+}-\mathrm{N}^{-} \mathrm{NO}_{2}^{-}-\mathrm{N}\right)$ with $60 \%$ of $\mathrm{NH}_{4}^{+}-\mathrm{N}$ conversion.

In another study by Ahn et al. [40], ANAMMOX process was developed to treat piggery wastewater $(56 \mathrm{~g} \mathrm{COD} / \mathrm{L}$ and $5 \mathrm{~g} \mathrm{TN} / \mathrm{L})$, using UASB reactor at $35^{\circ} \mathrm{C}$. The reactor was operated with $5 \mathrm{~d}$ HRT, with NLR of $0.43 \mathrm{~kg} \mathrm{NH}_{4}^{+}-\mathrm{N} / \mathrm{m}^{3} / \mathrm{d}$. To enable ANAMMOX process, Nitrogen loading rate was $0.36 \mathrm{~kg} \mathrm{NH}_{4}^{+}-\mathrm{N} / \mathrm{m}^{3} / \mathrm{d}$ and $0.5 \mathrm{~kg} \mathrm{NO}_{2}^{-}-\mathrm{N} / \mathrm{m}^{3} / \mathrm{d}$, using granular sludge of $18.6 \mathrm{~g}$ VS/L as seed biomass. The UASB was operated in semi continuous mode. At the end of the study, nitrogen conversion of 0.6 to $0.7 \mathrm{~g} \mathrm{TN} / \mathrm{L} / \mathrm{d}$ was achieved and the color of the biomass at the bottom of the reactor changed from dark gray to reddish brown, along with granulation of the ANAMMOX sludge in the lower part of reactor. The reddish brown color characteristic of the ANAMMOX enrichment was mainly attributed to the increase in cytochrome content [43]. Nearly $47 \%$ of $\mathrm{NH}_{4}^{+}-\mathrm{N}$ removal and $83 \% \mathrm{NO}_{2}^{-}-\mathrm{N}$ removal by ANAMMOX process was reported with the mean specific nitrogen removal to be 0.064 to $0.08 \mathrm{~g}$ TN $/ \mathrm{gVSS} / \mathrm{d}$. UASB reactor was also used by Ni et al. [52], for quick ANAMMOX enrichment from enriched ANAMMOX seed as compared to Ahn et al. who used a locally available seed for startup. The NLR achieved by Ni et al. [52] was $0.28 \mathrm{kgN} / \mathrm{m}^{3} / \mathrm{d}$ to $1 \mathrm{kgN} / \mathrm{m}^{3} / \mathrm{d}$ with HRT<1d.

Upflow Biofilter (UBF): Chen et al. (2010b) [48] successfully started up ANAMMOX process in an Upflow Biofilter with effluent recirculation at high loading rates $\left(34.5 \mathrm{kgN} / \mathrm{m}^{3} / \mathrm{d}\right)$. The high loading rates in ANAMMOX reactor was dependent on two parameters such as, the quantity and activity of functional biomass in the reactor. The seed used was taken from full-scale WWTP treating monosodium glutamate effluents of SS $(33.3 \mathrm{~g} / \mathrm{L})$ and VSS $(14.6 \mathrm{~g} / \mathrm{L})$. The reactor was fed with synthetic water and trace metals solution [43]. The ANAMMOX reactor was started with $(30$ to $50 \mathrm{mg} / \mathrm{L})$ of $\mathrm{NH}_{4}^{+}{ }^{+} \mathrm{N}$ and $(50$ to $70 \mathrm{mg} / \mathrm{L})$ of $\mathrm{NO}_{2}$ -N with HRT of 9.6h. HRT and substrate concentration was adjusted to increase the NLR, with the highest substrate concentrations of $976 \mathrm{mg} / \mathrm{L}$ of $\mathrm{NH}_{4}^{+}-\mathrm{N}$ and $1280 \mathrm{mg} / \mathrm{L}$ of $\mathrm{NO}_{2}-\mathrm{N}$. The recirculation was adopted in UBF to decrease the influent substrates in the ratio of 1:1, 2:1 and 4:1, especially till the effluent $\mathrm{NO}_{2}^{-}-\mathrm{N}$ concentrations was below $50 \mathrm{mg} / \mathrm{L}$. The UBF operation resulted in granulation and biofilm formation of ANAMMOX bacteria. Tang et al. [25] also used UBF that was inoculated with anaerobic granular sludge of SS $(51.2 \mathrm{~g} / \mathrm{L})$ and VSS $(43.5 \mathrm{~g} / \mathrm{L})$ originating from an UASB reactor treating paper mill wastewater. The UBF was operated at a fixed HRT of 9.1h and upon occurrence of ANAMMOX activity with continuous removal of $\mathrm{NH}_{4}{ }^{+}-\mathrm{N}$ and $\mathrm{NO}_{2}^{-}-\mathrm{N}$, the NLR was raised stepwise by adjusting the $\mathrm{NH}_{4}^{+}-\mathrm{N}$ and $\mathrm{NO}_{2}-\mathrm{N}$ concentrations. The inhibitory effects of high $\mathrm{pH}$ and $\mathrm{NH}_{3}$ on ANAMMOX bacteria were addressed in this study, since it affects the stabilization of the ANAMMOX process. The buffer concentration was increased from $0.5 \mathrm{~g} \mathrm{KHCO}_{3} / \mathrm{L}$ to $1.25 \mathrm{~g} \mathrm{KHCO}_{3} / \mathrm{L}$ to effectively reduce the $\mathrm{pH}$ variation, and to enhance the nitrogen removal performance of the reactor.

Membrane Bioreactor (MBR): Development of advanced biological system, such as MBR for startup of ANAMMOX process was considered as a better alternative for a quicker and stable system when compared to the other biological systems. Main limitation of SBR and other biofilm bioreactors which is the dependence of biomass retention on biomass settling was overcome by MBR. Cultivation of ANAMMOX bacteria as biofilms or cell aggregates in conventional biological systems can be beneficial from an applied, operation point of view. But based on microbiological, physiological and biochemical perspective, development of ANAMMOX bacteria as free cells is favored to avoid mass transfer and nutrient diffusion limitation experienced in biofilm bioreactors. Improvement of growth rate amongst free cells has been reported by Kartal et al. [53], with $K$. stuttgartiensis exhibiting doubling time of 11-20d in SBR compared to 7d in MBR. Successful cultivation of ANAMMOX bacteria with complete biomass retention, operated at high NLRs with production of ANAMMOX bacterial suspension as free cells or aggregates with high growth rate was achieved using MBR $[7,41]$.

In a study conducted by Wang et al. [4], with mixed activated 
Citation: Suneethi S, Sri Shalini S, Joseph K (2014) State of The Art Strategies for Successful ANAMMOX Startup and Development: A Review. Int J Waste Resources 4: 168. doi: 10.4172/2252-5211.1000168

Page 7 of 14

sludge as seed source (MLSS-2.23g/L ; MLVSS-1.52g/L) and synthetic wastewater of composition prescribed by Van de Graaf et al. [43], the MBR was operated with $<0.05 \mathrm{mg} / \mathrm{L}$ of DO concentration to enable ANAMMOX growth and metabolism. Within 2 months of operation, successful enrichment of ANAMMOX population as the dominant climax community was achieved. Trigo et al. [7] developed ANAMMOX as aggregates in Membrane Sequence Batch Reactor (MSBR). Complete mixing was performed using mechanical stirrer from 40 to $160 \mathrm{rpm}$. The reactor was operated in $6 \mathrm{~h}$ cycle comprising of $330 \mathrm{~min}$ of reaction, 9 min settling and 18 min discharge with permeate backwash for 3 min. At the end of $375 \mathrm{~d}$ of operation, 1.22 mole of $\mathrm{NO}_{2}-\mathrm{N}$ and 0.22 mole of $\mathrm{NO}_{3}^{-}-\mathrm{N}$ were consumed for 1.0 mole of $\mathrm{NH}_{4}^{+}-\mathrm{N}$ consumed.

ANAMMOX bacteria were cultivated as free cells in MBR in the study conducted by Van der Star et al. [41]. Enrichment medium and reduction of calcium and magnesium concentrations along with addition of yeast extract triggered the growth of ANAMMOX as free cells, reducing the appearance of flocs. Enriched granular ANAMMOX seed from a full-scale ANAMMOX reactor was used in this study. The reactor was operated for $>250 \mathrm{~d}$. At the end of the study, the $\mathrm{NO}_{2}^{-}-\mathrm{N}^{-} \mathrm{NH}_{4}^{+}{ }^{+} \mathrm{N}$ conversion ratio obtained was 1.1 to 1.3 , and $\mathrm{NO}_{3}{ }^{-}$ $-\mathrm{N}: \mathrm{NH}_{4}{ }^{+}-\mathrm{N}$ ratio was 0.10 to 0.25 . In another study by Suneethi and Joseph [54] where $96 \% \mathrm{NH}_{4}^{+}-\mathrm{N}$ removal efficiency was achieved with an influent Nitrogen loading rate of $5 \mathrm{~kg} \mathrm{NH}_{4}{ }^{+} \mathrm{N} / \mathrm{m}^{3} / \mathrm{d}$ within $129 \mathrm{~d}$. The performance in various biological systems applying ANAMMOX process is compared in Table 2.

\section{Key Signatures for Anammox Activity/Enrichment}

The prominent signatures applied for indicating the activity or enrichment of ANAMMOX bacteria includes both chemical and molecular nature. The details of which are entailed in 5.1 and 5.2.

\section{Chemical signatures}

pH: Changes in pH reversibly affect ANAMMOX activity. Optimal $\mathrm{pH}$ favorable for efficient ANAMMOX activity is in the range of 7 to 8
[12]. Instances of failures in $\mathrm{pH}$ control have resulted in unsuccessful attempts in ANAMMOX cultivation [12]. This usually leads to changes in concentrations of $\mathrm{NH}_{4}^{+}-\mathrm{N}, \mathrm{NO}_{2}^{-}-\mathrm{N}, \mathrm{NO}_{3}^{-}-\mathrm{N}$, which should be immediately addressed. Since increase in the growth of AOB and NOB instead of ANAMMOX will result in decrease in autotrophic ammonia removal by ANAMMOX activity.

$\mathbf{N}_{2} \mathbf{H}_{4}, \mathrm{NH}_{2} \mathrm{OH}$ : The concentrations of $\mathrm{N}_{2} \mathrm{H}_{4}$ and $\mathrm{NH}_{2} \mathrm{OH}$ in AnMBR [54] were around 0.03 to $0.001 \mathrm{mg} / \mathrm{L}$ (average of $0.011 \pm 0.008 \mathrm{mg} / \mathrm{L}$ ) and 0.08 to $0.33 \mathrm{mg} / \mathrm{L}$ (average of $0.055 \pm 0.107 \mathrm{mg} / \mathrm{L}$ ) respectively, confirming the AOB and ANAMMOX activity in the system $[8,55]$. The $\mathrm{N}_{2} \mathrm{H}_{4}$ generated from substrates $\mathrm{NH}_{4}^{+}-\mathrm{N}$ and $\mathrm{NO}_{2}^{-}-\mathrm{N}$ during ANAMMOX activity with $\mathrm{NO}$ as a direct precursor [56]. Changes in $\mathrm{N}_{2} \mathrm{H}_{4}$ concentration is usually corresponded to changes in $\mathrm{NO}_{2}^{-}-\mathrm{N}$ concentration. This could be attributed to the fact that when $\mathrm{NO}_{2}$ $-\mathrm{N}$ accumulation occurs inhibiting ANAMMOX activity, increased concentrations of $\mathrm{N}_{2} \mathrm{H}_{4}$ could be noticed [56]. Similarly the changes in the concentration of $\mathrm{NH}_{2} \mathrm{OH}$ coincided with the change in feed $\mathrm{NH}_{4}{ }^{+} \mathrm{N}$ concentration. $\mathrm{NH}_{2} \mathrm{OH}$ was reported to be an intermediate of ammonia oxidation carried out by $\mathrm{AOB}$, with increase in $\mathrm{NH}_{2} \mathrm{OH}$ meant an inhibition of HAO enzyme activity [56]. Since $\mathrm{NH}_{4}^{+}-\mathrm{N}$ is a common substrate for both $\mathrm{AOB}$ and ANAMMOX, change in feed $\mathrm{NH}_{4}^{+}-\mathrm{N}$ concentrations might have led to $\mathrm{NH}_{2} \mathrm{OH}$ buildup resulting in comparable tendencies of $\mathrm{NH}_{2} \mathrm{OH}$ with NLR [56].

$\mathrm{N}_{2} \mathrm{O}, \mathrm{NO}_{2}$, NO: In ANAMMOX enrichment units, production of $\mathrm{N}_{2} \mathrm{O}, \mathrm{NO}_{2}$, and $\mathrm{NO}$ occurs. The changes in gas concentrations corresponded to subtle changes in $\mathrm{N}_{2} \mathrm{H}_{4}$ and $\mathrm{NH}_{2} \mathrm{OH}$, with $\mathrm{NO}$ classified to be one of the intermediate in ANAMMOX reaction [56]. NO could be produced from $\mathrm{NH}_{2} \mathrm{OH}$ and $\mathrm{NO}_{2}^{-}-\mathrm{N}$ by $\mathrm{AOB}$ and ANAMMOX activity, respectively, while $\mathrm{N}_{2} \mathrm{O}$ generated from $\mathrm{NO}$ by $\mathrm{AOB}$ activity [57]. NO produced can also revert to $\mathrm{NO}_{2}^{-}-\mathrm{N}$ and then $\mathrm{NO}_{3}^{-}-\mathrm{N}$ by $\mathrm{NOB}$ activity. Denitrification process was also claimed to produce NO and $\mathrm{N}_{2} \mathrm{O}$ as well [57]. Not with standing such complexity in the sources of $\mathrm{NO}$ and $\mathrm{N}_{2} \mathrm{O}$ concentrations, the ultimate harmless $\mathrm{N}_{2}$ gas production could be resulted only by ANAMMOX and/or denitrification process.

\begin{tabular}{|c|c|c|c|c|c|c|c|}
\hline SI No & $\begin{array}{l}\text { Type of } \\
\text { Reactor }\end{array}$ & $\begin{array}{l}\text { Working } \\
\text { Volume (L) }\end{array}$ & $\begin{array}{l}\text { Duration of } \\
\text { operation (d) }\end{array}$ & HRT (d) & $\begin{array}{l}\text { Influent Nitrogen concentration } \\
\text { (mg/L) }\end{array}$ & $\begin{array}{l}\text { Nitrogen removal } \\
\text { efficiency }(\%)\end{array}$ & Reference \\
\hline & \multirow{2}{*}{ FBR } & \multirow{2}{*}{2.25} & 84 & $0.9-2$ & $\begin{array}{l}70-840\left(\mathrm{NO}_{2}^{-}-\mathrm{N}\right) \\
70-840\left(\mathrm{NH}_{4}^{+}-\mathrm{N}\right)\end{array}$ & $83-85$ & \multirow{2}{*}{ Strous et al. (1997) } \\
\hline & & & 150 & $0.1-11$ & $\begin{array}{c}70-840\left(\mathrm{NO}_{2}^{-}-\mathrm{N}\right) \\
1100-2100\left(\mathrm{NH}_{4}^{+}-\mathrm{N}\right)\end{array}$ & $81-99$ & \\
\hline & SBR & 7 & 150 & - & $\begin{array}{l}50-70\left(\mathrm{NO}_{2}^{-}-\mathrm{N}\right) \\
40-60\left(\mathrm{NH}_{4}^{+}-\mathrm{N}\right)\end{array}$ & $\begin{array}{c}100 \\
80\end{array}$ & $\begin{array}{l}\text { Chamchoi and Nitisoravut } \\
\text { (2007) }\end{array}$ \\
\hline & Gas lift & 7 & \multirow{2}{*}{200} & 1 & $\begin{array}{l}1100\left(\mathrm{NO}_{2}^{-}-\mathrm{N}\right) \\
900\left(\mathrm{NH}_{4}^{+}-\mathrm{N}\right)\end{array}$ & $\begin{array}{c}>99 \\
88\end{array}$ & \multirow{2}{*}{ Dapena-Mora et al. (2004a } \\
\hline & SBR & 1 & & 0.625 & $\begin{array}{l}375\left(\mathrm{NO}_{2}^{-}-\mathrm{N}\right) \\
375\left(\mathrm{NH}_{4}^{+}-\mathrm{N}\right)\end{array}$ & $\begin{array}{c}100 \\
78\end{array}$ & \\
\hline & Gas lift & 1.8 & - & 0.42 & $\begin{array}{l}1370\left(\mathrm{NO}_{2}^{-}-\mathrm{N}\right) \\
1360\left(\mathrm{NH}_{4}^{+}-\mathrm{N}\right)\end{array}$ & 83 & Sliekers et al. (2003) \\
\hline & $\mathrm{RBC}$ & 1.7 & 100 & 0.167 & $\begin{array}{l}350\left(\mathrm{NO}_{2}^{-}-\mathrm{N}\right) \\
350\left(\mathrm{NH}_{4}^{+}-\mathrm{N}\right)\end{array}$ & $\begin{array}{c}100 \\
99\end{array}$ & Liu et al. (2008) \\
\hline & UASB & 6 & 325 & 3.5 & 90 (total inorganic nitrogen) & 60 & Tran et al. (2006) \\
\hline & UBF & 8 & 236 & $0.06-0.2$ & $\begin{array}{l}331.5-1280\left(\mathrm{NO}_{2}^{-}-\mathrm{N}\right) \\
204.6-976\left(\mathrm{NH}_{4}^{+}-\mathrm{N}\right)\end{array}$ & 98.8 & Chen et al. (2010a) \\
\hline & MBR & 4.8 & 60 & 2 & $\begin{array}{l}50\left(\mathrm{NO}_{2}^{-}-\mathrm{N}\right) \\
50\left(\mathrm{NH}_{4}^{+}-\mathrm{N}\right)\end{array}$ & $\begin{array}{l}90 \\
90\end{array}$ & Wang et al. (2009) \\
\hline & MBR & 8 & $>250$ & 2 & $\begin{array}{l}552\left(\mathrm{NO}_{2}^{-}-\mathrm{N}\right) \\
552\left(\mathrm{NH}_{4}^{+}-\mathrm{N}\right)\end{array}$ & - & Van der Star et al. (2008) \\
\hline & MSBR & 5 & 375 & 1 & $\begin{array}{l}390\left(\mathrm{NO}_{2}^{-}-\mathrm{N}\right) \\
390\left(\mathrm{NH}_{4}^{+}-\mathrm{N}\right)\end{array}$ & $\begin{array}{l}90 \\
90\end{array}$ & Trigo et al. (2006) \\
\hline & AnMBR & 15 & 129 & 2 & $\begin{array}{c}100\left(\mathrm{NO}_{2}^{-}-\mathrm{N}\right) \\
10000\left(\mathrm{NH}_{4}^{+}-\mathrm{N}\right)\end{array}$ & $96 \%$ & $\begin{array}{l}\text { Suneethi and Joseph } \\
\text { (2011) }\end{array}$ \\
\hline
\end{tabular}

Table 2: ANAMMOX process performance in conventional and advanced biological reactors. 
Alongside these crucial elements, factors such as $\mathrm{pH}, \mathrm{HNO}_{2}$ and $\mathrm{DO}$ concentrations were also speculated to play a role in the $\mathrm{NO}, \mathrm{N}_{2} \mathrm{O}$ and $\mathrm{NO}_{x}$ gas emissions [57]. The production of $\mathrm{N}_{2} \mathrm{O}$ and $\mathrm{NO}$ by $\mathrm{AOBs}$ at low $\mathrm{O}_{2}$ conditions was reported, with especially a pure culture of Nitrosomonas generating $\mathrm{N}_{2} \mathrm{O}$ and $\mathrm{NO}$ only in the absence of $\mathrm{NO}_{2}^{-}-\mathrm{N}$ consumer such as Nitrobacter [58].

$\mathrm{NH}_{3}$ and $\mathrm{HNO}_{2}$ : The possibility of $\mathrm{NOB}$ inhibition by $\mathrm{NH}_{3}$ was supported by studies conducted by Anthonisen et al. [59]. Occurrence of unionized $\mathrm{NH}_{3}$ and $\mathrm{HNO}_{2}$ is dependent on the $\mathrm{pH}$ and temperature in the biological system and leads to inhibition of $\mathrm{NO}_{2}-\mathrm{N}$ conversion [60]. Presence of NOB (Nitrite Oxidizing Bacteria) inhibition is evident when $\mathrm{NH}_{3}$ concentration is above $0.1 \mathrm{mg} / \mathrm{L}[32,59,60]$. Likewise all nitrifying bacteria showed inhibition above $0.2 \mathrm{mg} / \mathrm{L}$ of $\mathrm{HNO}_{2}$ concentration as reported by other studies $[32,59]$.

$\mathrm{NH}_{4}^{+}-\mathrm{N}, \mathrm{NO}_{2}^{-}, \mathrm{NO}_{3}^{-}:$The concentration of nitrite during the startup is of crucial importance for growth: a too low amount will result in substrate limitation and thus slower growth, while concentrations above $50-150 \mathrm{mg} \mathrm{N} / \mathrm{L}$ can already lead to inhibition [14,50,61]. The stoichiometric ratio for $\mathrm{NH}_{4}^{+}-\mathrm{N}$ removed: $\mathrm{NO}_{2}^{-}-\mathrm{N}$ converted: $\mathrm{NO}_{3}$ $-\mathrm{N}$ produced indicating the ANAMMOX process was 1:1.32:0.26 [12]. During the buildup of Nitrogen Loading rate, low influent $\mathrm{NO}_{2}-\mathrm{N} / \mathrm{NH}_{4}{ }^{+}-\mathrm{N}$ ratio could be observed with the overall obtained ratio was 1:0.84:0.02 [62]. Wyffels et al. [63] reported $0.20 \mathrm{~mol}$ of production of $\mathrm{NO}_{3}-\mathrm{N}$ per mol of $\mathrm{NH}_{4}^{+}-\mathrm{N}$ oxidized for ANAMMOX MBR system. Low degree but significant occurrence of ANAMMOX process, of approximately 1:1.15 for $\mathrm{NO}_{2}^{-}-\mathrm{N}$ consumption to $\mathrm{NH}_{4}{ }^{+}-\mathrm{N}$ consumption, was reported by Wang et al. [4] and about 1.05 by Wyffels et al. [63]. Denitrification process could also affect the effluent $\mathrm{NO}_{2}$ $-\mathrm{N}$ to $\mathrm{NH}_{4}^{+}-\mathrm{N}$ molar ratio [64]. The molar ratio of $\mathrm{NO}_{2}-\mathrm{N}$ conversion to $\mathrm{NH}_{4}^{+}-\mathrm{N}$ removed of 1.22 while the $\mathrm{NO}_{3}^{-}-\mathrm{N}$ production to $\mathrm{NH}_{4}^{+}-\mathrm{N}$ oxidized ratio of 0.22 was obtained by Trigo et al. [7].

Alkalinity and dissolved oxygen: Feed alkalinity along with DO concentrations are critical controlling parameters in a single-stage biological process for nitrogen removal. The control of alkalinity and dissolved oxygen (DO) concentrations in the feed to maintain an alkalinity to ammonia ratio of $<8$ and $\mathrm{DO}$ of $<0.06 \mathrm{mg} \mathrm{O} / \mathrm{mg} \mathrm{N} / \mathrm{d}$, respectively, was necessary for inhibiting nitratation and enhancing partial nitritation and ANAMMOX [45].

To achieve a biological nitrogen removal in a single-stage, the activity of NOB has to be inhibited without affecting the activities of AOB and ANAMMOX bacteria. These three groups of microorganisms are closely interlinked with common electron donor and acceptors. From the works of Gong et al. [19] and Paredes et al. [23] it has been reported that by regulating the concentration of $\mathrm{DO}$ and $\mathrm{NO}_{2}^{-}-\mathrm{N}$, partial control of NOB activity could be achieved. As NOB competes for $\mathrm{DO}$ and $\mathrm{NO}_{2}-\mathrm{N}$ with $\mathrm{AOB}$ and ANAMMOX bacteria, respectively in the absence of $\mathrm{NO}_{2}^{-}-\mathrm{N}$ in wastewater, $\mathrm{NOB}$ depends directly on AOB for their source of electron donor. By limiting DO concentration, AOB consume available $\mathrm{DO}$ for $\mathrm{NO}_{2}-\mathrm{N}$ production. Hence, under this condition, NOB experiences two-way limitations, initially in terms of electron donor $\left(\mathrm{NO}_{2}^{-}-\mathrm{N}\right)$ and later in terms of electron acceptor $\left(\mathrm{O}_{2}\right)$. $\mathrm{AOB}, \mathrm{NOB}$ and ANAMMOX bacteria which are chemolithotrophic microorganisms also require inorganic carbon source for their cell growth [65]. By controlling bicarbonate alkalinity, the process of elimination of NOB can be further fine-tuned [45]

\section{Molecular signatures}

The common methodological approaches adopted to detect, identify and confirm ANAMMOX bacteria or their activity includes: (i) Detection of the single ladderane lipids as biomarkers, which were reported to be unique structures, found in the intracytoplasmic organelle like structure of ANAMMOX bacteria by HPLC - Atmospheric Pressure Ionization - MS and GC - MS [66]. The compound specific stable carbon isotope ratios can also be monitored by GC - IR - MS system [67].

(ii) Chemical analyses of the Nitrogen compounds to detect the change in the concentrations of $\mathrm{NH}_{4}^{+}-\mathrm{N}, \mathrm{NO}_{2}^{-}-\mathrm{N}$ and $\mathrm{NO}_{3}^{-}-\mathrm{N}$ owing to ANAMMOX activity [60] along with determination of $\mathrm{N}_{2} \mathrm{H}_{4}$ and $\mathrm{NH}_{2} \mathrm{OH}$ [67]

(iii) Analysis of gas composition of $\mathrm{N}_{2}, \mathrm{~N}_{2} \mathrm{O}, \mathrm{NH}_{3}, \mathrm{CO}_{2}, \mathrm{CH}_{4}$ by GC - TCD [40,41], or only the gas composition analysis of $\mathrm{N}_{2} \mathrm{O}$ carried out in real-time using gas-filter correlation (Teledyne API 320E).

(iv) Estimation of NO (nitric oxide) using a chemiluminescence detector (CLD) [41], or determination of $\mathrm{NO}$ and $\mathrm{NO}_{2}$ by chemiluminescence method (Ecophysics CLD 64 monitor).

(v) Application of molecular techniques such as Polymerase Chain Reaction (PCR) or Fluorescence In Situ Hybridization (FISH), which are based on the nucleic acid analysis for identification. A number of specific sequences and primers were developed to amplify the 16S rRNA from the environmental and enrichment samples using the PCR based approach or by FISH analysis, as detailed in 5.2.2 [4,11,37,69].

(vi) Application of ISR FISH to assess the precursor rRNA concentration in a cell, the intergenic spacer region (ISR) between $16 \mathrm{~S}$ rRNA gene and 23S rRNA gene by targeting using fluorescently labeled oligonucleotide probes [67].

(vii) Combination of Fluorescence In Situ Hybridization Micro Autoradiography (FISH-MAR) that can directly link the uptake of radioactively labeled substrate $\left(\mathrm{Eg}: \mathrm{NaH}_{14} \mathrm{CO}_{3}\right)$ with uncultured organisms such as ANAMMOX [67].

(viii) Quantification of changes in microbial population of a mixed culture of nitrifiers, denitrifiers, NOBs, AOBs and ANAMMOX using quinone profiles, since this profile is usually represented as the mole fraction of each quinone type that is specific for a microbial community [70].

(ix) Observation of ANAMMOX cells using confocal micrographs or scanning electron microscope (SEM). The observations from SEM images are subject to confirmation using molecular analyses $[4,615,22]$.

(x) Trace experiments with labeled $\left[{ }_{15} \mathrm{~N}\right] \mathrm{NH}_{4}{ }^{+}-\mathrm{N}$ reacts uniquely, in a 1:1 ratio with unlabeled $\left[{ }_{14} \mathrm{~N}\right] \mathrm{NO}_{2}-\mathrm{N}$ to $\mathrm{N}_{2}\left({ }_{14} \mathrm{~N}_{15} \mathrm{~N}\right)$ in the ANAMMOX reaction.

SEM observation of ANAMMOX seed biomass: Scanning electron microscope images were used to visualize the seed and membrane morphology in AnMBR by Suneethi and Joseph [54]. The seed cultivated in the AnMBR and the biomass on the membrane surface were mostly spherical and elliptical bacterial clusters with rough surface, interspersed with abundant aggregates of inorganic origin. This observation together with monitoring of the nitrogen transformations revealed the presence of ANAMMOX activity. There was also presence of few filamentous and short rod bacteria, indicating the harmonious coexistence of ANAMMOX bacteria with other microbial populations like AOBs, NOBs and denitrifiers in AnMBR [4,22]. The SEM photographs of the cultivated ANAMMOX sludge in AnMBR indicated 
the various bacterial morphologies found in the sludge, though the cause of filamentous bacteria formation was unclear.

Biomass growth occurred as granules with an irregular cauliflower appearance, which was reported by Trigo et al. [7]. Dapena-Mora et al. [71] described the ANAMMOX biomass growth in SBR-ANAMMOX system as granular with an irregular cauliflower appearance. Presence of co-existence of cocci bacteria such as filamentous and short rod bacteria with spherical shaped bacteria in the seed sludges from activated sludge and anaerobic digestion sludge was reported by Chamchoi and Nitisoravut [6]. Negative role played by filamentous bacteria in system performance in UASB seed sludge was reported by Chamchoi and Nitisoravut [6]. Frequent appearance and development of Chlorobi- like filamentous bacteria in ANAMMOX reactors, was also reported by $\mathrm{Li}$ et al. [9]. The relation between the filamentous bacteria and ANAMMOX seed could be typically linked to unconfirmed metabolic connection with the involvement of the filamentous bacteria in bestowing structural integrity to the ANAMMOX in both granular and biofilm phase $[11,69]$.

The SEM observations of the enriched ANAMMOX seeds were reported by Chamchoi and Nitisoravut [6] as spherical flocs of ANAMMOX sludge with smooth surfaces along with cocci and filamentous type bacteria. The seed sludge from UASB exhibited both filamentous and spherical shaped bacteria while the seed sludge from activated sludge and anaerobic digestion sludge, the main types of bacteria were spherical and short rod-shaped bacteria. The spherical cells were presumed to be ANAMMOX that coexisted harmoniously with $\mathrm{AOBs}$ and $\mathrm{NOBs}$ as observed from various bacterial morphologies. The cause for occurrence of filamentous bacteria was inconclusive in their study.

ANAMMOX identification: Usually the color of the ANAMMOX enriched sludge is reported to be reddish brown, which is a welldocumented characteristic of ANAMMOX activity $[6,7,38,41]$. The recent detection methods and different molecular techniques available for the ANAMMOX organisms are fluorescence in situ hybridization (FISH), 16S rRNA or functional gene analysis, membrane lipids and tracer experiments with $\left[{ }_{15} \mathrm{~N}\right]$ labeled ammonia [3,72-78]. FISH can give both quantitative and qualitative figures of ANAMMOX bacterial population. In situ hybridizations with DNA probes for the detection of ANAMMOX bacteria are performed with fluorescent labeled compounds and fluorescent bacterial cells, which are detected by epifluorescent microscopy, confocal laser scanning microscopy or flow cytometry. The number of FISH probes targeting the specific ANAMMOX organisms is given in the Table 3. FISH signal intensity is directly proportional to the precursor rRNA concentrations in ANAMMOX cells and could be used as a direct measure of the growth rate (ribosome turnover rate) of the ANAMMOX organisms. The advantages of analyzing with FISH technique are reliable, with reduced misinterpret artifacts, conveys about the spatial location of bacteria and density in a limited region without the destruction of the sample. But if large amount of inert material was present and when the ANAMMOX bacterial cell was low in the sample (i.e. low numbers of rRNA) then the FISH technique may not be applied since the detection will not be possible in microscopy. In that case, the 16S rRNA or functional gene-based approach i.e. PCR amplification with $16 \mathrm{~S}$ rRNA gene-targeted primers and phylogenetic analysis of the product is an excellent technique. Some ANAMMOX specific FISH probes are used as PCR primers for the specific amplification of the 16S rRNA genes of ANAMMOX organisms. The different PCR primer pairs for the ANAMMOX identification along with its PCR conditions are listed in the Table 4 are used for analyzing the entire group of ANAMMOX organisms. Disadvantages of PCR are low DNA extraction yield and the production of artifacts after PCR. Selection of an appropriate DNA extraction method should be carried out [76]. Real time quantitative PCR (RT-qPCR) and competitive PCR (cPCR) could also be used to find the ANAMMOX bacterial mass based on 16S rRNA or functional genes. qPCR is widely used as it is cheaper when compared to Competitive PCR which has lower accuracy. When compared to FISH, qPCR has higher throughput, more reliability and more sensitive quantification $[9,74]$. Functional genes like Hydrazine oxidoreductase (hzo) gene can be used as a biomarker in ANAMMOX detection, since it is reported to be an intermediate in ANAMMOX process to dehydrogenate $\mathrm{N}_{2} \mathrm{H}_{4}$ to convert it into $\mathrm{N}_{2}$. The different primers targeting the hzo gene is given in the Table 4 along with their operating conditions and target length.

Inhibitor/Stimulator for ANAMMOX activity: The effects on the ANAMMOX activity due to addition of various inhibitors/stimulators are summarized in the Table 5. According to Strous et al. [14], 1gN/L for $\mathrm{NH}_{4}^{+}-\mathrm{N}$ and $\mathrm{NO}_{3}^{-}-\mathrm{N}$ respectively, has no effect. Whereas $100 \mathrm{mg} / \mathrm{L}$

\begin{tabular}{|c|c|c|c|c|c|c|c|}
\hline SI No & Probe & Specificity & Sequence & Target site & $\begin{array}{c}\text { Formamide } \\
\text { concentration (\%) }\end{array}$ & $\begin{array}{l}\text { Wash buffer } \\
\mathrm{NaCl}(\mathrm{mM})\end{array}$ & Reference \\
\hline & Pla46 & \multirow{2}{*}{ Planctomycetales } & GACTTGCATGCCTAATCC & $46-63^{a}$ & 30 & 112 & $\begin{array}{l}\text { Neef et al. 1998; } \\
\text { Kartal et al. } 2007\end{array}$ \\
\hline & Pla886 & & GCCTTGCGACCATACTCCC & - & 35 & - & Neef et al. 1998 \\
\hline & Amx368 & $\begin{array}{l}\text { All ANAMMOX } \\
\text { microorganisms }\end{array}$ & CCTTTCGGGCATTGCGAA & $368-385^{a}$ & 15 & 338 & $\begin{array}{c}\text { Schmid et al. 2003; Kartal et } \\
\text { al. } 2007\end{array}$ \\
\hline & Amx820 & \multirow{4}{*}{$\begin{array}{l}\text { Candidatus "Brocadia } \\
\text { Anammoxidans" }\end{array}$} & AAAACСССТСTACTTAGTGCCC & $820-841^{a}$ & $\begin{array}{l}25 \\
40 \\
25\end{array}$ & $\begin{array}{c}159 \\
56 \\
56\end{array}$ & $\begin{array}{l}\text { Egli et al. 2001; } \\
\text { Schmid et al. 2000; } \\
\text { Mobarry et al. } 1996\end{array}$ \\
\hline & Amx432 & & GTTAACTCCCGACAGTGG & - & 40 & - & Schmid et al. 2000 \\
\hline & Amx997 & & TTTCAGGTTTCTACTTCTACC & - & 20 & - & Schmid et al. 2000 \\
\hline & Amx1240 & & TTTAGCATCCCTTTGTACCAACC & - & 60 & 14 & Egli et al. 2001 \\
\hline & Apr 820 & $\begin{array}{c}\text { Candidatus } \\
\text { "Anammoxoglobus } \\
\text { propionicus" }\end{array}$ & AAACCССTCTACCGAGTGCCC & $820-840^{a}$ & 40 & 56 & Kartal et al. 2007 \\
\hline & Kst1273 & $\begin{array}{c}\text { Candidatus "Kuenenia } \\
\text { stuttgartiensis" }\end{array}$ & TCGGCTTTATAGGTTTCGCA & - & 25 & 159 & $\begin{array}{l}\text { Schmid et al. 2000; Egli et al. } \\
2001\end{array}$ \\
\hline
\end{tabular}

a(16S rRNA position E.Coli numbering)

Table 3: Probes used in FISH technique for ANAMMOX identification. 
Citation: Suneethi S, Sri Shalini S, Joseph K (2014) State of The Art Strategies for Successful ANAMMOX Startup and Development: A Review. Int J Waste Resources 4: 168. doi: 10.4172/2252-5211.1000168

Page 10 of 14

\begin{tabular}{|c|c|c|c|c|c|c|c|}
\hline SI No & Probe & Specificity & Sequence & $\begin{array}{l}\text { Condition } \\
\left({ }^{\circ} \mathrm{C}\right)\end{array}$ & $\begin{array}{c}\text { Formamide } \\
\text { concentration (\%) }\end{array}$ & $\begin{array}{l}\text { Wash buffer } \\
\mathrm{NaCl}(\mathrm{mm})\end{array}$ & Reference \\
\hline & $\mathrm{Pla} 46 \mathrm{~F}$ & Planctomycetales & GACTTGCATGCCTAATCC & $\begin{array}{c}58 \\
46-63\end{array}$ & 25 & 159 & $\begin{array}{l}\text { Neef et al. 1998; } \\
\text { Schmid et al. } 2005\end{array}$ \\
\hline & Pla886 & $\begin{array}{c}\text { Isosphaera, } \\
\text { Gemmata, Pirellula, } \\
\text { Planctomyces }\end{array}$ & GCCTTGCGACCATACTCCC & - & 30 & 112 & $\begin{array}{l}\text { Neef et al. 1998; } \\
\text { Schmid et al. } 2005\end{array}$ \\
\hline & $\begin{array}{c}\text { First run PCR } \\
\text { PLA46F\& PLA886R } \\
\text { Second run PCR } \\
\text { P338F \& P518R }\end{array}$ & \multirow{3}{*}{ Planctomycetales } & - & $\begin{array}{l}56 \\
63\end{array}$ & - & - & Pynaert et al. 2003 \\
\hline & $\begin{array}{c}\text { PLA40F \& P518R } \\
\text { P338F, P338-IIF \& P518R }\end{array}$ & & - & $\begin{array}{l}60 \\
53\end{array}$ & - & - & Pynaert et al. 2003 \\
\hline & $\begin{array}{l}\text { Pla46F } \\
\text { 1390R }\end{array}$ & & $\begin{array}{l}\text { GGATTAGGCATGCAAGTC } \\
\text { ACGGGCGGTGTGTACAA }\end{array}$ & 59 & - & - & Li et al. 2009 \\
\hline & $\begin{array}{c}\mathrm{Pla} 46 \mathrm{~F} \\
\mathrm{Am} \times 667 \mathrm{R}\end{array}$ & $\begin{array}{l}\text { 16S rRNA } \\
\text { ANAMMOX }\end{array}$ & $\begin{array}{l}\text { GGATTAGGCATGCAAGTC } \\
\text { ACCAGAAGTTCCACTCTC }\end{array}$ & $\begin{array}{l}57 \\
56\end{array}$ & - & - & $\begin{array}{l}\text { Neef et al. 1998; } \\
\text { Yapsakli et al. } 2011\end{array}$ \\
\hline & $\begin{array}{c}\mathrm{Pla} 46 \mathrm{~F} \\
\mathrm{Am} \times 368 \mathrm{R}\end{array}$ & \multirow{2}{*}{$\begin{array}{l}\text { All ANAMMOX } \\
\text { microorganisms }\end{array}$} & $\begin{array}{l}\text { GACTTGCATGCCTAATCC } \\
\text { CCTTTCGGGCATTGCGAA }\end{array}$ & $\begin{array}{l}59\left({ }^{(} 300\right) \\
52\left({ }^{\circ} 323\right)\end{array}$ & - & - & $\begin{array}{l}\text { Schmid et al. 2003; } \\
\quad \text { Li et al. } 2010\end{array}$ \\
\hline & Amx368F/R & & CCTTTCGGGCATTGCGAA & 56 & 15 & 338 & $\begin{array}{l}\text { Schmid et al. 2003; } \\
\text { Kartal et al. } 2007\end{array}$ \\
\hline & Amx809F & \multirow{3}{*}{ ANAMMOX bacteria } & GCCGTAAACGATGGGCACT & '809-826 & - & - & $\begin{array}{l}\text { Tsushima et al. } \\
\quad 2007\end{array}$ \\
\hline & Amx818F & & ATGGGCACTMRGTAGAGGGGTTT & '818-839 & - & - & $\begin{array}{l}\text { Tsushima et al. } \\
2007\end{array}$ \\
\hline & Amx1066R & & AACGTCTCACGACACGAGCTG & c1047-1066 & - & - & $\begin{array}{l}\text { Tsushima et al. } \\
2007\end{array}$ \\
\hline & $\begin{array}{l}\text { Amx808F } \\
\text { Amx1040R }\end{array}$ & $\begin{array}{l}\text { AnAOB } 16 S \text { rRNA } \\
\text { gene }\end{array}$ & $\begin{array}{l}\text { ARCYGTAAACGATGGGCACTAA } \\
\text { CAGCCATGCAACACCTGTRATA }\end{array}$ & 60 & - & - & Li et al. 2009 \\
\hline & $\begin{array}{l}\text { Amx694F } \\
\text { Amx960R }\end{array}$ & \multirow{3}{*}{ ANAMMOX bacteria } & $\begin{array}{l}\text { GGGGAGAGTGGAACTTCGG } \\
\text { GCTCGCACAAGCGGTGGAGC }\end{array}$ & $\begin{array}{l}{ }^{\circ} 694-713 \\
{ }^{c} 960-979\end{array}$ & - & - & Jetten et al. 1999 \\
\hline & $\begin{array}{l}\text { Brod541F } \\
\text { Brod1260R }\end{array}$ & & $\begin{array}{l}\text { GAGCACGTAGGTGGGTTTGT } \\
\text { GGATTCGCTTACCTCTCGG }\end{array}$ & $60\left({ }^{c} 720\right)$ & - & - & Li et al. 2010 \\
\hline & $\begin{array}{l}\text { Brod541F } \\
\text { Amx820R }\end{array}$ & & $\begin{array}{l}\text { GAGCACGTAGGTGGGTTTGT } \\
\text { AAAACCCCTCTACTTAGTGCCC }\end{array}$ & $59\left({ }^{(} 280\right)$ & - & - & Li et al. 2010 \\
\hline & $\begin{array}{l}\text { Pla46F } \\
\text { Amx820R }\end{array}$ & \multirow{4}{*}{$\begin{array}{l}\text { Candidatus } \\
\text { "Brocadia } \\
\text { Anammoxidans"/ } \\
\text { Candidatus } \\
\text { Kuenenia }\end{array}$} & $\begin{array}{c}\text { GACTTGCATGCCTAATCC } \\
\text { AAAACCCCTCTACTTAGTGCCC }\end{array}$ & $\begin{array}{l}59(\mathrm{c} 780) \\
52\left({ }^{(} 775\right)\end{array}$ & - & - & $\begin{array}{l}\text { Schmid et al. } 2000 \text {; } \\
\text { Li et al. } 2010\end{array}$ \\
\hline & $\begin{array}{l}\text { Amx368F } \\
\text { Amx820R }\end{array}$ & & $\begin{array}{c}\text { TTCGCAATGCCCGAAAGG } \\
\text { AAAACCCCTCTACTTAGTGCCC }\end{array}$ & $\begin{array}{l}{ }^{c} 368-385 \\
{ }^{c} 820-841\end{array}$ & - & - & $\begin{array}{l}\text { Schmid et al. 2003; } \\
\text { Schmid et al. } 2000\end{array}$ \\
\hline & Amx820 F/R & & AAAACСССТСТАСТTAGTGCCC & 56 & $\begin{array}{l}25 \\
40\end{array}$ & $\begin{array}{c}159 \\
56\end{array}$ & $\begin{array}{c}\text { Egli et al. 2001; } \\
\text { Schmid et al. } 2000\end{array}$ \\
\hline & Amx1900 & & САTCTCCGGCTTAACAA & - & 30 & 112 & $\begin{array}{l}\text { Schmid et al. 2000; } \\
\text { Schmid et al. } 2001\end{array}$ \\
\hline & Kst0288 & \multirow{6}{*}{$\begin{array}{l}\text { Candidatus } \\
\text { "Kuenenia } \\
\text { stuttgartiensis" }\end{array}$} & GCGCAAAGAAATCAAACTGG & - & 10 & 450 & Schmid et al. 2001 \\
\hline & Kst0193 & & CAGACCGGACGTATAAAAG & - & 10 & 450 & Schmid et al. 2001 \\
\hline & Kst0077 & & TTTGGGCCACACTCTGTT & - & 10 & 450 & Schmid et al. 2001 \\
\hline & Kst0031 & & ATAGAAGCCTTTTGCGCG & - & 10 & 450 & Schmid et al. 2001 \\
\hline & Kst1275 & & TCGGCTTTATAGGTTTCGCA & - & 25 & 159 & Schmid et al. 2000 \\
\hline & Kst0157 & & GTTCCGATTGCTCGAAAC & - & 25 & 159 & $\begin{array}{l}\text { Schmid et al. 2001, } \\
\text { Schmid et al. } 2005\end{array}$ \\
\hline & Ban0389 & \multirow{13}{*}{$\begin{array}{l}\text { Candidatus } \\
\text { "Brocadia } \\
\text { Anammoxidans" }\end{array}$} & GGATCAAATTGCTACCCG & - & 10 & 450 & Schmid et al. 2001 \\
\hline & Ban0222 & & GCTTAGAATCTTCTGAGGG & - & 10 & 450 & Schmid et al. 2001 \\
\hline & Ban0108 & & TTTGGGCCCGCAATCTCA & - & 10 & 450 & Schmid et al. 2001 \\
\hline & Ban0071 & & СССТАССАСАAАССТСGТ & - & 10 & 450 & Schmid et al. 2001 \\
\hline & Amx1240 & & TTTAGCATCCCTTTGTACCAACC & - & 60 & 14 & Schmid et al. 2000 \\
\hline & Amx1154 & & TCTTGACGACAGCAGTCT & - & 20 & 225 & Schmid et al. 2000 \\
\hline & Amx1015 & & GATACCGTTCGTCGCCCT & - & 60 & 14 & Schmid et al. 2000 \\
\hline & Amx0997 & & TTTCAGGTTTCTACTTCTACC & - & 20 & 225 & Schmid et al. 2000 \\
\hline & Amx0613 & & CCGCCATTCTTCCGTTAAGCGG & - & 40 & 56 & Schmid et al. 2000 \\
\hline & Amx0432 & & CTTAACTCCCGACAGTGG & - & 40 & 56 & Schmid et al. 2000 \\
\hline & Amx0223 & & GACATTGACСССТСТСTG & - & 40 & 56 & Schmid et al. 2000 \\
\hline & Amx0156 & & CGGTAGCCCAATTGCTT & - & 40 & 56 & Schmid et al. 2000 \\
\hline & Ban0162 & & CGGTAGCCCCAATTGCTT & - & 40 & 56 & Schmid et al. 2000 \\
\hline & BS820R & $\begin{array}{c}\text { Candidatus } \\
\text { "Scalindua wagneri / } \\
\text { sorokinii" }\end{array}$ & TAATTCССTСTACTTAGTGCCC & 56 & 40 & 56 & Schmid et al. 2000 \\
\hline
\end{tabular}


Citation: Suneethi S, Sri Shalini S, Joseph K (2014) State of The Art Strategies for Successful ANAMMOX Startup and Development: A Review. Int J Waste Resources 4: 168. doi: 10.4172/2252-5211.1000168

Page 11 of 14

\begin{tabular}{|c|c|c|c|c|c|c|}
\hline Scabr1114R & $\begin{array}{c}\text { Candidatus } \\
\text { "Scalindua brodae" }\end{array}$ & CCCGCTGGTAACTAAAAACAAG & 56 & 20 & 225 & $\begin{array}{l}\text { Schmid et al. 2003; } \\
\text { Schmid et al. } 2005\end{array}$ \\
\hline Sca1309R & $\begin{array}{l}\text { Candidatus } \\
\text { "Scalindua" }\end{array}$ & TGGAGGCGAATTTCAGCCTCC & 56 & 5 & 675 & $\begin{array}{l}\text { Schmid et al. 2003; } \\
\text { Schmid et al. } 2005\end{array}$ \\
\hline \multicolumn{7}{|c|}{ Targeting hzo gene } \\
\hline $\begin{array}{l}\text { hzocl1F1 } \\
\text { hzocl1R2 }\end{array}$ & \multirow{5}{*}{ AnAOB hzo gene } & $\begin{array}{l}\text { TGYAAGACYTGYCAYTGG } \\
\text { ACTCCAGATRTGCTGACC }\end{array}$ & $\begin{array}{l}50 \mathrm{C} \\
\left({ }^{\circ} 470\right)\end{array}$ & - & - & Schmid et al. 2008 \\
\hline $\begin{array}{l}\text { hzocl1F2 } \\
\text { hzocl1R2 }\end{array}$ & & $\begin{array}{l}\text { TGYAAGACYTGYCAYTGGG } \\
\text { ACTCCAGATRTGCTGACC }\end{array}$ & $\begin{array}{l}53 C \\
\left({ }^{\circ} 470\right)\end{array}$ & - & - & Schmid et al. 2008 \\
\hline $\begin{array}{l}\text { Ana-hzo 1F } \\
\text { Ana-hzo 2R }\end{array}$ & & $\begin{array}{l}\text { TGTGCATGGTCAATTGAAAG } \\
\text { ACCTCTTCWGCAGGTGCAT }\end{array}$ & $\begin{array}{c}53 \\
\left({ }^{c} 1000\right)\end{array}$ & - & - & Li et al. 2010 \\
\hline $\begin{array}{l}\text { hzoF1h } \\
\text { hzoR1 }\end{array}$ & & $\begin{array}{l}\text { TGTGCATGGTCAATTGAAAG } \\
\text { CAACCTCTTCWGCAGGTGCATG }\end{array}$ & $\begin{array}{c}53 \\
\left({ }^{c} 1000\right)\end{array}$ & - & - & Li et al. 2010 \\
\hline $\begin{array}{l}\text { Ana-hzo1f } \\
\text { Ana-hzo2r }\end{array}$ & & $\begin{array}{l}\text { TGTGCATGGTCAATTGAAAG } \\
\text { ACCTCTTCWGCAGGTGCAT }\end{array}$ & 53 & - & - & Li et al. 2010 \\
\hline
\end{tabular}

cPCR product length (-bp)

Table 4: Probes used in PCR for ANAMMOX identification.

\begin{tabular}{|c|c|c|c|c|c|}
\hline SI No & $\begin{array}{l}\text { ANAMMOX activity } \\
\text { inhibitor /stimulator }\end{array}$ & Mode of action & $\begin{array}{l}\text { Concentration or } \\
\text { period tested }\end{array}$ & Effect & Reference \\
\hline & \multirow{5}{*}{ Ammonium } & \multirow{5}{*}{-} & $1 \mathrm{gN} / \mathrm{L}$ & No effect & Strous et al. 1999; Bettazi et al. 2010 \\
\hline & & & $55 \mathrm{mM}$ & $50 \%$ inhibition & Dapena-Mora et al. 2007; Bettazi et al. 2010 \\
\hline & & & $>70 \mathrm{mgN} / \mathrm{L}$ & $\begin{array}{l}\text { Free ammonia } \\
\text { inhibition }\end{array}$ & Jung et al. 2007; Bettazi et al. 2010 \\
\hline & & & $13-90 \mathrm{mg} \mathrm{NH}_{4}{ }^{+}-\mathrm{N} / \mathrm{L}$ & Negative effect & Waki et al. 2007; Bettazi et al. 2010 \\
\hline & & & $90 \mathrm{mg} \mathrm{NH}_{4}^{+}-\mathrm{N} / \mathrm{L}$ & No effect & Bettazi et al. 2010 \\
\hline & \multirow{3}{*}{ Nitrate } & \multirow{3}{*}{-} & $1 \mathrm{gN} / \mathrm{L}$ & No effect & Strous et al. 1999; Bettazi et al. 2010 \\
\hline & & & $45 \mathrm{mM}$ & $50 \%$ inhibition & Dapena-Mora et al. 2007; Bettazi et al. 2010 \\
\hline & & & $57 \mathrm{mg} \mathrm{NO}_{3}^{-}-\mathrm{N} / \mathrm{L}$ & No effect & Bettazi et al. 2010 \\
\hline & \multirow{7}{*}{ Nitrite } & \multirow{7}{*}{-} & $100 \mathrm{mgNO}_{2}^{-\mathrm{N} / \mathrm{L}}$ & Complete inhibition & Strous et al. 1999; Bettazi et al. 2010 \\
\hline & & & $>13.2 \mathrm{mM}$ & No activity & Egli et al. 2001; Bettazi et al. 2010 \\
\hline & & & $25 \mathrm{mM}$ & $50 \%$ inhibition & Dapena-Mora et al. 2007; Bettazi et al. 2010 \\
\hline & & & $70 \mathrm{mgNO}_{2}-\mathrm{N} / \mathrm{L}$ & Activity decrease & Jung et al. 2007; Bettazi et al. 2010 \\
\hline & & & $>100 \mathrm{mgNO}_{2}^{-\mathrm{N} / \mathrm{L}}$ & Inhibition & Lopez et al. 2008; Bettazi et al. 2010 \\
\hline & & & $60 \mathrm{mgNO}_{2}-\mathrm{N} / \mathrm{L}$ (spiked) & Activity decrease & Bettazi et al. 2010 \\
\hline & & & $\begin{array}{l}>30 \mathrm{mgNO}_{2}-\mathrm{N} / \mathrm{L} \\
\text { (long exposure) }\end{array}$ & Activity decrease & Bettazi et al. 2010 \\
\hline & No biomass & None & $0 \mathrm{mg} / \mathrm{L}$ & No activity & Jetten et al. 1999 \\
\hline & Sterilization at $121^{3} \mathrm{C}$ & Denaturation & $20-120 \mathrm{~min}$ & No activity & Jetten et al. 1999 \\
\hline & Gamma irradiation & Inactivation & $60 \mathrm{~min}$ & No activity & Jetten et al. 1999 \\
\hline & Penicillin V & $\begin{array}{l}\text { Inhibition of cell wall } \\
\text { synthesis of bacteria }\end{array}$ & $0-100 \mathrm{mg} / \mathrm{L}$ & None & Jetten et al. 1999 \\
\hline & Penicillin G & - & $0-1000 \mathrm{mg} / \mathrm{L}$ & None & Jetten et al. 1999 \\
\hline & Bromoethane sulfonic acid & $\begin{array}{c}\text { Inhibition of } \\
\text { methanogenesis }\end{array}$ & $0-20 \mathrm{mM}$ & None & Jetten et al. 1999 \\
\hline & $\mathrm{Na}_{2} \mathrm{SO}_{4}$ & $\begin{array}{l}\text { Stimulation of sulphate } \\
\text { reduction }\end{array}$ & $20 \mathrm{mM}$ & None & Jetten et al. 1999 \\
\hline & $\mathrm{Na}_{2} \mathrm{MoO}_{4}$ & $\begin{array}{l}\text { Inhibition of sulphate } \\
\text { reduction }\end{array}$ & $20 \mathrm{mM}$ & None & Jetten et al. 1999 \\
\hline & Chloramphenicol & $\begin{array}{l}\text { Inhibition of protein } \\
\text { synthesis }\end{array}$ & $0-400 \mathrm{mg} / \mathrm{L}$ & None & Jetten et al. 1999 \\
\hline & Hydrazine & $\begin{array}{l}\text { Inhibition of } \mathrm{NH} 2 \mathrm{OH} \\
\text { oxidation }\end{array}$ & 0-3 mM & Activation & Jetten et al. 1999 \\
\hline & Acetone & Solvent for $\mathrm{N}$-serve & $10 \mathrm{mM}$ & None & Jetten et al. 1999 \\
\hline & $\mathrm{N}$-serve & Inhibition of nitrification & $0-50 \mathrm{mg} / \mathrm{L}$ & None & Jetten et al. 1999 \\
\hline & Allylthiourea & Inhibition of nitrification & $0-10 \mathrm{mM}$ & None & Jetten et al. 1999 \\
\hline & Acetylene & $\begin{array}{l}\text { Inhibition of nitrification } \\
\text { and denitrification }\end{array}$ & $6 \mathrm{mM}$ & Inhibition & Jetten et al. 1999 \\
\hline & 2,4-Dinitrophenol & Uncoupler & $0-400 \mathrm{mg} / \mathrm{L}$ & Inhibition & Jetten et al. 1999 \\
\hline & $\begin{array}{c}\text { Carbonyl cyanide } \\
\text { m-chlorophenylhydrazone }\end{array}$ & Uncoupler & $0-40 \mathrm{mg} / \mathrm{L}$ & Inhibition & Jetten et al. 1999 \\
\hline & $\mathrm{HgCl}_{2}$ & Cell damage & $0-300 \mathrm{mg} / \mathrm{L}$ & Inhibition & Jetten et al. 1999 \\
\hline & Oxygen & Oxidative stress & $0-0.2 \mathrm{mM}$ & Inhibition & Jetten et al. 1999 \\
\hline
\end{tabular}


Citation: Suneethi S, Sri Shalini S, Joseph K (2014) State of The Art Strategies for Successful ANAMMOX Startup and Development: A Review. Int J Waste Resources 4: 168. doi: 10.4172/2252-5211.1000168

Page 12 of 14

\begin{tabular}{|c|c|c|c|c|}
\hline \multirow{4}{*}{ Phosphate } & \multirow{4}{*}{ Chelating agent } & $<1 \mathrm{mM}$ & None & $\begin{array}{c}\text { Jetten et al. 1999; } \\
\text { Dapena-Mora et al. } 2007\end{array}$ \\
\hline & & $>2 \mathrm{mM}$ & Inhibition & Jetten et al. 1999 \\
\hline & & 5 or $50 \mathrm{mM}$ & Loss of activity & Van de Graaf et al. 1996; Dapena-Mora et al. 2007 \\
\hline & & $21 \mathrm{mM}$ & $50 \%$ inhibition & Dapena-Mora et al. 2007 \\
\hline \multirow{2}{*}{ Sulphide } & \multirow{2}{*}{-} & 1 or $5 \mathrm{mM}$ & Increase & Van de Graaf et al. 1996; Dapena-Mora et al. 2007 \\
\hline & & $0.3 \mathrm{mM}$ & $50 \%$ inhibition & Dapena-Mora et al. 2007 \\
\hline \multirow[t]{2}{*}{ Chloride } & \multirow[t]{2}{*}{ - } & $50 \mathrm{mM}$ & No effect & $\begin{array}{l}\text { Van de Graaf et al. 1996; } \\
\text { Dapena-Mora et al. } 2007\end{array}$ \\
\hline & & $200 \mathrm{mM}$ & $50 \%$ inhibition & Dapena-Mora et al. 2007 \\
\hline \multirow{3}{*}{ Acetate } & \multirow{3}{*}{-} & 1 or $5 \mathrm{mM}$ & Increase & Van de Graaf et al. 1996; Dapena-Mora et al. 2007 \\
\hline & & $39 \mathrm{mM}$ & $50 \%$ inhibition & Dapena-Mora et al. 2007 \\
\hline & & $50 \mathrm{mM}$ & $70 \%$ of inhibition & Dapena-Mora et al. 2007 \\
\hline \multirow{3}{*}{ Oxygen } & \multirow{3}{*}{ - } & $0.5 \%$ & Reversibly inhibited & Van Dongen et al. 2001 \\
\hline & & $0.06 \mathrm{mg} / \mathrm{L}$ & Reversibly Inhibition & Paredes et al. 2007 \\
\hline & & $\begin{array}{c}1 \mu \mathrm{M} \text { (>18 \% oxygen } \\
\text { saturation) }\end{array}$ & Irreversibly Inhibition & Zhang et al. 2008 \\
\hline Organic matter & - & $300 \mathrm{mg} \mathrm{COD/L}$ & Inactivation & Chamchoi et al. 2008 \\
\hline Methanol & - & $<1 \mathrm{mM}$ & Inhibition & $\begin{array}{l}\text { Guven et al. } 2004 \\
\text { Kartal et al. } 2004\end{array}$ \\
\hline Ethanol & - & $<1 \mathrm{mM}$ & Inhibition & $\begin{array}{l}\text { Guven et al. 2004; } \\
\text { Kartal et al. } 2004\end{array}$ \\
\hline
\end{tabular}

Table 5: Inhibitor/Stimulator for ANAMMOX activity.

of $\mathrm{NO}_{2}^{-}-\mathrm{N}$ cause complete inhibition. Biomass plays an important role in the ANAMMOX process; if no biomass available then the activity was not observed [79]. When subjecting the biomass with gamma radiation or sterilization, no change in the $\mathrm{NH}_{4}^{+}-\mathrm{N}$ or $\mathrm{NO}_{2}^{-} \mathrm{N}$ was noticed showing no activity until the 60-120 min. Around 10-20 $\mathrm{mM}$ concentration of the compounds such as Penicillin V, Penicillin G, Bromoethane sulfonic acid, Sodium sulphate, Sodium molybdate, Chloramphenicol, Acetone and Allylthiourea has no effect on the ANAMMOX activity [79]. But with chemical compounds such as Methanol, Ethanol and sulphide even with very low concentrations of $1 \mathrm{mM}$ has inhibition over ANAMMOX activity. The Oxygen from 0.2 to $200 \mathrm{mM}$ has an oxidative stress on the ANAMMOX bacteria $[21,80]$. $50 \mathrm{mM}$ of acetate resulted in $70 \%$ of inhibition in the ANAMMOX process [15]. Phosphate concentrations higher than $180 \mathrm{mg} / \mathrm{L}$ and $\mathrm{NH}_{3}$ with higher concentration inhibit ANAMMOX activity [23]. Trace amounts of either of the ANAMMOX intermediates $\mathrm{N}_{2} \mathrm{H}_{4}(>1.4$ $\mathrm{mgN} / \mathrm{L})$ and $\mathrm{NH}_{2} \mathrm{OH}(>0.7 \mathrm{mgN} / \mathrm{L})$ can activate the ANAMMOX process $[14,18,45,81]$.

\section{Conclusions}

Some of the challenges facing successful ANAMMOX startup and development include slow growth rate, operational difficulty and long startup time. With dedicated enrichment and cultivation techniques the sensitivity of ANAMMOX bacteria to inhibitory concentrations of $\mathrm{NO}_{2}^{-}-\mathrm{N}$, Alkalinity, $\mathrm{O}_{2}$ etc., could be minimized and ANAMMOX bacteria could be successfully developed to yield sustained $\mathrm{NH}_{4}{ }^{+} \mathrm{N}$ removal. With the key parameters such as the source of seed, type of reactors used, operational strategy, experimental conditions and molecular signatures such as PCR, FISH, SEM and the inhibitors and affinity factors being monitored and optimized, ANAMMOX startup and development could be deemed successful.

\section{Acknowledgement}

The support of the University Grants Commission Research Fellowship for meritorious scholars in Sciences to the corresponding author is gratefully acknowledged.

\section{References}

1. Mulder A, Graaf AAV, Robertson LA, Kuenen JG (1995) Anaerobic ammonium oxidation discovered in a denitrifying fluidized bed reactor. FEMS Microbiology Reviews 16: 177-184.

2. Berge ND, Reinhart DR. Townsend TG (2005) The Fate of Nitrogen in Bioreactor Landfills. Critical Reviews in Environmental Science and Technology 35: 365-399.

3. Pynaert K, Smets BF, Wyffels S, Beheydt D, Siciliano SD, et al. (2003) Characterization of an autotrophic nitrogen-removing biofilm from a highly loaded lab-scale rotating biological contactor. Appl Environ Microbiol. 69: 3626-3635.

4. Wang T, Zhang H, Yang F, Liu S, Fu Z, et al. (2009) Startup of the ANAMMOX process from the conventional activated sludge in a membrane bioreactor Bioresource Technology 100: 2501-2506.

5. Kimura $Y$, Isaka K, Kazama $F$ (2011) Effects of inorganic carbon limitation on anaerobic ammonium oxidation (Anammox) activity. Bioresource technology 102: 4390-4394.

6. Chamchoi N, Nitisoravut S (2007) ANAMMOX enrichment from different conventional sludges. Chemosphere 66: 2225-2232.

7. Trigo C, Campos JL, Garridio JM, Mendez R (2006) Startup of the ANAMMOX process in a membrane bioreactor. Journal of Biotechnology 126: 475-487.

8. Third KA, Paxman J, Schmid M, Strous M, Jetten MSM, et al. (2005) Enrichment of ANAMMOX from Activated Sludge and its Application in the CANON process. Microb Ecol 459: 236-244.

9. Li X, Du B, Fu H, Wang R, Shi J, et al. (2009) The bacterial diversity in an anaerobic ammonium-oxidizing (Anammox) reactor community. Syst Appl Microbiol 32: 278-289.

10. Strous M, Pelletier E, Mangenot S, Rattei T, Lehner A, et al. (2006) Deciphering the evolution and metabolism of an Anammox bacterium from a community genome. Nature, 440: 790-794.

11. Park H, Rosenthal A, Jezek ., Ramalingam K, Fillos J, et al. (2010) Impact of inocula and growth mode on the molecular microbial ecology of anaerobic ammonia oxidation (Anammox) bioreactor communities. Water Res 44: 50055013.

12. Strous M, Heijnen JJ, Kuenen JG, Jetten MSM (1998) The sequencing batch reactor as a powerful tool for the study of slowly growing anaerobic ammoniumoxidizing microorganisms. Applied Microbiology and Biotechnology 50: 598596

13. Van der Star WRL, Abma WR, Blommers D, Mulder JW, Tokutomi T, et al (2007) Startup of reactors for anoxic ammonium oxidation: Experiences from the first full scale Anammox reactor in Rotterdam. Water Res 41: 4149 - 4163. 
Citation: Suneethi S, Sri Shalini S, Joseph K (2014) State of The Art Strategies for Successful ANAMMOX Startup and Development: A Review. Int J Waste Resources 4: 168. doi: 10.4172/2252-5211.1000168

14. Strous M, Kuenen JG, Jetten MSM (1999) Key physiology of anaerobic ammonium oxidation. Appl Environ Microbiol 65: 3248-3250.

15. Dapena-Mora A, Campos JL, Mosquerra-Corral A, Jetten MSM, Mendez R (2004) Stability of the ANAMMOX process in a gas - lift reactor and a SBR. Journal of Biotechnology 110: 159-170.

16. Date $\mathrm{Y}$, Isaka K, Ikuta H, Sumino T, Kaneko N, et al. (2009) Microbial diversity of Anammox bacteria enriched from different types of seed sludge in an anaerobic continuous-feeding cultivation reactor. J of Biosci Bioeng 107: 281-286.

17. Strous M, van Gerven E, Kuenen JG, Jetten MSM. (1997) Effects of Aerobic and Microaerobic Conditions on Anaerobic Ammonium-Oxidizing (Anammox) Sludge. Appl Environ Microbiol 63: 2446-2448.

18. Xu G, Xu X, Yang F, Liu S, Gao Y (2012) Partial nitrification adjusted by hydroxylamine in aerobic granules under high DO and ambient temperature and subsequent Anammox for low $\mathrm{C} / \mathrm{N}$ wastewater treatment. Chemical Engineering Journal 213: 338-345.

19. Gong Z, Yang F, Liu S, Bao H, Hu S, et al. (2007) Feasibility of a membrane aerated biofilm reactor to achieve single - stage autotrophic nitrogen removal based on Anammox. Chemosphere 69: 776-784.

20. Uyanik S, Bekmezci OK, Yurtsever A (2011) Strategies for successful ANAMMOX enrichment at laboratory scale. Clean-Soil, Air, Water 39: 653-657.

21. Kartal B, de Almeida NM, Maaclke W, den Camp O, Jetten MSM, et al. (2013) How to make a living from anaerobic ammonium oxidation. FEMS Microbio Rev 37: 428-461.

22. Arrojo B, Mosquera-Corral A, Campos JL, Mendez R (2006) Effects of mechanical stress on Anammox granules in a sequencing batch reactor (SBR). J Biotechnol 123: 453-463.

23. Paredes D, Kuschk P, Mbwette TSA, Stange F, Muller RA, et al. (2007) New aspects of Microbial Nitrogen Transformations in the Context of Wastewater treatment - A Review. Engineering and Life Science 7: 13-25.

24. Strous M, Gerven V, Zheng P, Kuenen JG, Jetten MSM (1997) Ammonium removal from concentrated waste streams with the anaerobic ammonium oxidation (Anammox) process in different reactor configurations. Water Research 31: 1955-1962.

25. Tang CJ, Zheng P, Mahmood Q, Chen JW (2009) Startup and inhibition analysis of the Anammox process seeded with anaerobic granular sludge. $J$ Ind Microbiol Biotechnol 36: 1093-1100.

26. Siegrist $H$, Reithaar $S$, Lais $P(1998)$ Nitrogen loss in a nitrifying rotating contactor treating ammonium rich leachate without organic carbon. Water Science and Technology, 37: 589-591.

27. Xu Z., Zhaohui Y., Guangming Z., Yong X., Jiuhua D. (2007) Mechanism studies on nitrogen removal when treating ammonium-rich leachate by sequencing batch biofilm reactor. Frontiers of Environmental Science and Engineering in China 1: 43-48.

28. Guo ZH, Qi ZS (2006) Treating leachate mixture with anaerobic ammonium oxidation technology. Journal of Central South University of Technology 6 : 663-667.

29. Sliekers AO, Third KA, Abma W, Kuenen JG, Jetten MSM (2003) CANON and Anammox in a gas-lift reactor. FEMS Microbiol Lett 218: 339-344.

30. Liang Z, Liu J (2008) Landfill Leachate Treatment with a novel process: Anaerobic ammonium oxidation (Anammox) combined with soil infiltration system. J Hazard Mater 151: 202-212.

31. Liang Z, Liu JX, Li J (2009) Decomposition and mineralization of aquatic humic substances (AHS) in treating landfill leachate using the Anammox process. Chemosphere 74: 1315-1320.

32. Furukawa K, Inatomi Y, Qiao S, Quan L, Yamamoto T, et al. (2009) Innovative treatment system for digester liquor using ANAMMOX process. Bioresource Technology 100: 5437-5443.

33. Fux C, Boehler M, Huber P, Brunner I, Siegrist H (2002) Biological treatment of ammonium-rich wastewater by partial nitritation and subsequent anaerobic ammonium oxidation (Anammox) in a pilot plant. Journal of Biotechnology 99 295-306.

34. Gali A, Dosta J, Loosdrecht MV, Alvarez JM (2007) Two ways to achieve an Anammox influent from real reject water treatment at lab-scale: Partial SBR nitrification and SHARON process. Process Biochemistry 42: 715-720.
35. Yamamoto T, Wakamatsu, Qiao S, Hira D, Fujii T, et al. (2011) Partial nitritation and Anammox of a livestock manure digester liquor and analysis of its microbial community. Bioresour Technol 102: 2342-2347.

36. Ganigue R, Gabarro J, Sanchez-Melsio A, Ruscalleda M, Lopez H, et al. (2009) Long-term operation of a partial nitritation pilot plant treating leachate with extremely high ammonium concentration prior to an Anammox process. Bioresour Technol 100: 5624-5632.

37. Sanchez-Melsio A, Caliz J, Balaguer MD, Colprim J, Vila X (2009) Development of batch-culture enrichment coupled to molecular detection for screening of natural and man-made environments in search of Anammox bacteria for N-removal bioreactors systems. Chemosphere 75: 169-179.

38. Tran HT, Park YJ, Cho MK, Kim DJ, Ahn DH (2006) Anaerobic Ammonium Oxidation Process in an Upflow Anaerobic Sludge Reactor with Granular Sludge selected from an anaerobic digester. Biotechnology and Bioprocess Engineering 11: 199-204.

39. Liu S, Yang F, Gong Z, Chen H, Xue Y, et al. (2008) The enrichment of ANAMMOX bacteria in non - woven rotating biological contactor reactor. The 2nd International Conference on Bioinformatics and Biomedical Engineering 3315-3318.

40. Ahn YH, Hwang IS, Min KS (2004) Anammox and partial denitritation in anaerobic nitrogen removal from piggery waste. Water Sci Technol 49: 145153

41. Van der Star RLW, Miclea AI, Dongen UGJOMV, Muyzer G, Picioreanu C, et al (2008) The Membrane Bioreactor: A Novel tool to grow ANAMMOX Bacteria as free cells. Biotechnol Bioeng 101: 286-294.

42. Liao D, Li X, Yang Q, Zhao Z, Zeng G (2007) Enrichment and granulation of Anammox biomass started up with methanogenic granular sludge. World Journal of Microbiology Biotechnology 23: 1015-1020.

43. van de Graaf AA, Bruijn PD, Robertson LA, Jetten MSM, Kuenen JG (1996) Autotrophic growth of anaerobic ammonium oxidizing microorganisms in a fluidized bed reactor. Microbiology 142: 2187-2196.

44. Kawagoshi Y, Nakamura Y, Kawashima H, Fujisaki K, Fujimoto A, et al. (2009) Enrichment culture of marine anaerobic ammonium oxidation (Anammox) bacteria from sediment of sea-based waste disposal site. J Biosci Bioeng 107 61-63.

45. Bagchi S, Biswas R., Nandy T (2010) Alkalinity and Dissolved Oxygen as Controlling Parameters for Ammonia Removal through Partial Nitritation and ANAMMOX in a Single-stage Bioreactor. J Ind Microbiol Biotechnol 37: 871876

46. Chen J, Ji Q, Zheng P, Chen T, Wang C (2010a) floatation and control of granular sludge in a high-rate anammox reactor. Water Research 1-8.

47. Pathak BK, Kazama F, Tanaka Y (2007) Quantification of anammox populations enriched in an immobilized microbial consortium with low levels of ammonium nitrogen and at low temperature. Journal of Bacteriology 1173-1179.

48. Chen J, Zheng P, Yi Y, Tang C, Mahmood Q (2010) Promoting sludge quantity and activity results in high loading rates in anammox UBF. Bioresour Technol 101: 2700-2705

49. Schmid MC, Walsh K, Webb RI, Rijpstra WIC, van de Pas-Schoonen K, et al. (2003) Candidatus "Scalindua brodae", sp nov, Candidatus "Scalindua wagneri", sp. nov., two new species of anaerobic ammonium oxidizing bacteria. Syst Appl Microbiol 26: 529-538.

50. Egli K, Fanger U, Alvarez PJJ, Siegrist H, Van der Meer JR, et al. (2001) Enrichment and characterization of an Anammox bacterium from a rotating biological contactor treating ammonium-rich leachate. Arch Microbiol 175 198-207.

51. Chen HH, Liu ST, Yang FL, Xue Y, Wang T (2009) The development of simultaneous partial nitrification, ANAMMOX and denitrification (SNAD) process in a single reactor for nitrogen removal. Bioresour Technol 100: 1548-1554.

52. Ni SQ, Gao BY, Wang CC, Lin JG, Sung S (2011) Fast startup, performance and microbial community in a pilot scale Anammox reactor seeded with exotic mature granules. Bioresour Technol 102: 2448-2454.

53. Kartal B, Niftrik LV, Sliekers O, Schmid MC, Schmidt I, et al. (2004) Application, eco-physiology and biodiversity of anaerobic ammonium-oxidizing bacteria. Reviews in Environmental Science and Biotechnology $3:$ 255-264.

54. Suneethi S, Joseph K (2011) ANAMMOX process startup and stabilization with an anaerobic seed in Anaerobic Membrane Bioreactor (AnMBR). Bioresour Technol 102: 8860-8867. 
Citation: Suneethi S, Sri Shalini S, Joseph K (2014) State of The Art Strategies for Successful ANAMMOX Startup and Development: A Review. Int J Waste Resources 4: 168. doi: 10.4172/2252-5211.1000168

Page 14 of 14

55. Shivaraman N, Shivaraman G (2003) ANAMMOX-A novel microbial process for ammonium removal. Current Science 84: 1507-1508.

56. Kartal B, Maalcke WJ, de Almeida NM, Cirpus I, Gloerich J, et al. (2011) Molecular mechanism of anaerobic ammonium oxidation. Nature 479: 127 130

57. Chandran K, Stein LY, Klotz MG, Van Loosdrecht MCM (2011) Nitrous Oxide Production by Lithotrophic Ammonia-oxidizing Bacteria and Implications for Engineered Nitrogen removal Systems. Biochem Soc Trans 39): 1832-1837.

58. Kester R ., Deboer W, Laanbroek HJ (1997) Production of NO and $\mathrm{N}_{2} \mathrm{O}$ by pure cultures of nitrifying and denitrifying bacteria during changes in aeration. Appl Environ Microbiol 63: 3872-3877.

59. Anthonisen AC, Loehr RC, Prakasam TBS, Srinath EG (1976) Inhibition of nitrification by ammonia and nitrous acid. Journal of Water pollution control Fed 48: 835-852.

60. Yamamoto T, Takaki K, Koyama T, Furukawa K (2008) Long-term stability of partial nitritation of swine wastewater digester liquor and its subsequent treatment by ANAMMOX. Bioresour Technol 99: 6419-6425.

61. Dapena-Mora A, Fernandez I, Campos JL, Mosquera-Corral A, Mendez R, et al. (2007) Evaluation of activity and inhibition effects on Anammox process by batch tests based on the nitrogen gas production. Enzyme and Microbial Technology 40: 859-865.

62. Suneethi S, Joseph K (2013) Autotrophic ammonia removal from landfil leachate in Anaerobic Membrane Bioreactor (AnMBR). Environ Technol 34: 3161-3167.

63. Wyffels S, Boeckx P, Pynaert K, Zhang D, Van Cleemput O, et al. (2004) Nitrogen removal from sludge reject water by a two-stage oxygen-limited autotrophic nitrification denitrification process. Water Sci Technol 49: 57-64.

64. Ganigue R, Gabarró J, López H, Ruscalleda M, Balaguer MD, et al. (2010) Combining Partial Nitritation and Heterotrophic Denitritation for the Treatment of Landfill Leachate Previous to an Anammox Reactor. Water Sci Technol 61: 1949-1955.

65. Kuai L, Verstraete W (1998) Ammonium removal by the oxygen - limited autotrophic nitrification - denitrification system. Appl Environ Microbiol 64 4500-4506.

66. Van Niftrik LA, Fuerst JA, Damste JSS, Kuenen JG, Jetten MSM, et al. (2004) The anammoxosome: an intracytoplasmic compartment in Anammox bacteria. FEMS Microbiol Lett 233: 7-13

67. Jetten MS, Cirpus IEY, Kartal B, van Niftrik LAMP, van de Pas-Schoonen K et al. (2005) $1994-2004$ : 10 years of research on the anaerobic oxidation of ammonium. Biochem Soc Trans 33: 119-123.

68. Cho S, Takahashi Y, Fujii N, Yamada Y, Satoh H, et al. (2010) Nitrogen removal performance and microbial community analysis of an anaerobic upflow granular bed ANAMMOX reactor. Chemosphere, 78: 1129-1135.
69. Park H, Rosenthal A, Ramalingam K, Fillos J, Chandran K (2010) Linking community profiles, gene expression and $\mathrm{N}$-removal in Anammox bioreactors treating municipal anaerobic digestion reject water. Environ Sci Technol 44 6110-6116.

70. Sinha B, Annachhatre AP (2007) Assessment of partial nitritation reacto performance through microbial population shift using quinone profile, FISH and SEM. Bioresour Technol 98: 3602-3610.

71. Dapena-Mora A, Arrojo B, Campos JL, Mosquera-Corral A, Mendez R (2004b) Improvement of the settling properties of Anammox sludge in an SBR. Journal of Chemical Technology and Biotechnology 79: 1412-1420.

72. Kartal B, Rattray J, van Niftrik LA, van de Vossenberg J, Schmid MC, et al (2007) Candidatus "Anammoxoglobus propionicus" A new propionate oxidizing species of anaerobic ammonium oxidizing bacteria. Syst Appl Microbiol 30: 39-49.

73. Neef A., Amann R, Schlesner H, Schleifer KH (1998) Monitoring a widespread bacterial group: in situ detection of planctomycetes with 16S rRNA-targeted probes. Microbiology-UV 144: 3257-3266.

74. Tsushima I, Kindaichi T, Okabe S (2007) Quantification of anaerobic ammoniumoxidizing bacteria in enrichment cultures by real-time PCR. Water Research 41 785-794.

75. Schmid M, Twachtmann U, Klein M, Strous M, Juretschko S, et al. (2000) Molecular evidence for genus level diversity of bacteria capable of catalyzing anaerobic ammonium oxidation. Syst Appl Microbiol. 23: 93-106.

76. Schmid MC, Maas B, Dapena A, Pas-schoonen KVD, Vossenberg JVD, et al (2005) Biomarkers for In Situ Detection of Anaerobic Ammonium-Oxidizing (Anammox) Bacteria. Appl Environ Microbiol 71 : 1677-1684.

77. Schmid MC, Hooper AB, Klotz MG, Woebken D, Lam P, et al. (2008) Environmental detection of octahaem cytochrome $c$ hydroxylamine/hydrazine oxidoreductase genes of aerobic and anaerobic ammonium-oxidizing bacteria. Environ Microbiol 10: 3140-3149.

78. Li M, Hong Y, Klotz MG, Gu JD (2010) A comparison of primer sets for detecting 16S rRNA and hydrazine oxidoreductase genes of anaerobic ammoniumoxidizing bacteria in marine sediments. Appl Microbiol Biotechnol 86: 781 790.

79. Jetten MSM, Strous M, Pas-schoonen KTVD, Schalk J, Dongen UGJMV, et al (1999) The anaerobic oxidation of ammonium. FEMS Microbiology Reviews 22: $421-437$.

80. Jung JY, Kang SH, Chung YC, Ahn DH (2007) Factors affecting the activity of Anammox bacteria during Startup in the continuous culture reactor. Water Sci Technol 55: 459-468.

81. Bettazzi E, Simone C, Claudia V, Claudio L (2010) Nitrite Inhibition and Intermediates Effects on Anammox Bacteria: A Batch-scale Experimental Study. Process Biochemistry 45: 573-580. 